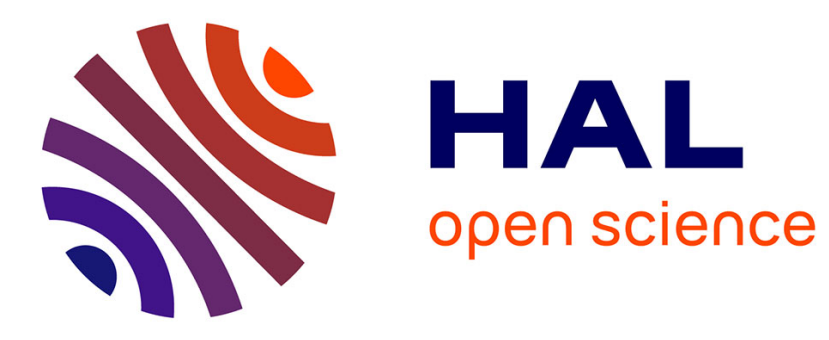

\title{
Detection and discrimination of various oil-contaminated soils using vegetation reflectance
}

\author{
Guillaume Lassalle, Sophie Fabre, Anthony Crédoz, Rémy Hédacq, Pierre \\ Borderies, Georges Bertoni, Thierry Erudel, Evelyne Buffan-Dubau, \\ Dominique Dubucq, Arnaud Elger
}

\section{To cite this version:}

Guillaume Lassalle, Sophie Fabre, Anthony Crédoz, Rémy Hédacq, Pierre Borderies, et al.. Detection and discrimination of various oil-contaminated soils using vegetation reflectance. Science of the Total Environment, 2019, 655, pp.1113-1124. 10.1016/j.scitotenv.2018.11.314 . hal-02084118

\section{HAL Id: hal-02084118 \\ https://hal.science/hal-02084118}

Submitted on 29 Mar 2019

HAL is a multi-disciplinary open access archive for the deposit and dissemination of scientific research documents, whether they are published or not. The documents may come from teaching and research institutions in France or abroad, or from public or private research centers.
L'archive ouverte pluridisciplinaire HAL, est destinée au dépôt et à la diffusion de documents scientifiques de niveau recherche, publiés ou non, émanant des établissements d'enseignement et de recherche français ou étrangers, des laboratoires publics ou privés. 


\section{Detection and discrimination of various oil-}

\section{contaminated soils using vegetation reflectance}

Guillaume Lassalle $^{\mathrm{a}, \mathrm{b}}$, Sophie Fabre ${ }^{\mathrm{a}}$, Anthony Credoz ${ }^{\mathrm{b}}$, Rémy Hédacq ${ }^{\mathrm{b}}$, Pierre Borderies ${ }^{\mathrm{a}}$, Georges Bertoni ${ }^{\mathrm{c}}$,Thierry Erudel ${ }^{\mathrm{a}, \mathrm{c}}$, Evelyne Buffan-Dubau ${ }^{d}$,Dominique Dubucq ${ }^{\mathrm{e}}$, Arnaud Elger $^{\mathrm{d}}$

\section{AUTHOR ADDRESS}

${ }^{a}$ Office National d'Études et de Recherches Aérospatiales (ONERA), Toulouse, France

${ }^{\mathrm{b}}$ TOTAL S.A., Pôle d'Études et de Recherches de Lacq, Lacq, France

${ }^{\mathrm{c}}$ DYNAFOR, Université de Toulouse, INRA, Castanet-Tolosan, France

${ }^{\mathrm{d}}$ EcoLab, Université de Toulouse, CNRS, INPT, UPS, Toulouse, France

${ }^{\mathrm{e}}$ TOTAL S.A., Centre Scientifique et Technique Jean-Féger, Pau, France

*Corresponding author: Guillaume Lassalle, Office National d’Études et de Recherches Aérospatiales, 2 Avenue Edouard Belin, 31055 Toulouse, France; E-mail:

guillaume.lassalle@onera.fr

Keywords: remote sensing, hyperspectral spectroscopy, total petroleum hydrocarbons, heavy metal, vegetation index, pigment 


\section{ABSTRACT}

The use of hyperspectral spectroscopy for oil detection recently sparked a growing interest for risk assessment over vegetated areas. In a perspective of image applications, we conducted a greenhouse experiment on a brownfield-established species, Rubus fruticosus L. (bramble), to evaluate the potential of vegetation reflectance to detect and discriminate among various oilcontaminated soils. The species was grown for 32 days on four different soils with mixtures of petroleum hydrocarbons and heavy metals. Additional plants were grown on either uncontaminated control or water-deficient soils for comparison. Repeated reflectance measurements indicated modified spectral signatures under both oil and water-deficit exposure, from leaf to multi-plant scales. The amplitude of the response varied with mixture composition, exposure time, acquisition scale and spectrum region. Reflectance changes were linked to alterations in chlorophyll, carotenoid and water contents using vegetation indices. These indices were used to catch spectral similarities among acquisition scales and to discriminate among treatments using Kendall's coefficient of concordance (W) and regularized logistic regression. Of the 33 vegetation indices tested, 14 were concordant from leaf to multi-plant scales $(\mathrm{W}>$ $0.75, \mathrm{p}<0.05)$ and strongly related to leaf biochemistry $\left(\mathrm{R}^{2}>0.7\right)$. The 14 indices allowed discriminating between each mixture and the control treatment with no or minor confusions $(\leq 5$ $\%)$ at all acquisition scales, depending on exposure time. Some of the mixtures remained difficult to discriminate among them and from the water-deficit treatment. The approach was tested at the canopy scale under natural conditions and performed well for identifying bramble exposed to either one of the experimentally-tested mixtures (90\% accuracy) or to uncontaminated soil (83 $\%$ accuracy). This study provided better understanding of vegetation spectral response to oil mixtures and opens up promising perspectives for future applications. 


\section{Introduction}

In oil and gas industry, exploration and production activities require efficient detection of total petroleum hydrocarbons (TPH) for assessing environmental risks from accidental leakages (Logan et al. 2010, Wang et al. 1999). For both purposes, active and passive remote sensing have recently raised a growing interest (Angelliaume et al.2017, Konik \& Bradtke 2016, Leifer et al. 2012). Thanks to high spectral resolution, hyperspectral remote sensing revealed to be particularly efficient onshore (Scafutto et al. 2017). For example, direct oil detection can be achieved by analyzing the spectral signature of soils at wavelengths corresponding to light absorption of TPH (Scafutto et al. 2016, Asadzadeh \& de De Souza Filho 2016). However, this technique implies the presence of apparent oil at the surface, so its application on-shore is restricted to bare soils and not effective in densely vegetated areas. As a solution, recent studies suggest to detect oil indirectly, through its effects on vegetation health (Credoz et al. 2016, Noomen et al. 2012, Sanches et al. 2013a).

TPH and heavy metals (HM) present in oil both affect vegetation biochemical and biophysical parameters related to leaf optical properties (Athar et al. 2016, Balliana et al. 2017, Baruah et al. 2014, Nagajyoti et al. 2010). Authors noticed alterations of leaf anatomy, pigment and water contents under TPH and HM exposure, resulting in reflectance modifications at corresponding wavelengths (Lassalle et al. 2017, Rosso et al. 2005, Sanches et al. 2013a, Zhu et al. 2014). By exploiting these modifications, it is thus possible to detect oil in soils from the spectral signature of vegetation. For such purpose, vegetation indices (VI) provided encouraging results but remain underexploited (Arellano et al. 2015, Emengini et al. 2013a, Lassalle et al. 2017).

Although the reliability of TPH and HM detection has been demonstrated experimentally, its application from airborne and satellite hyperspectral images leads to the apparition of false 
alarms (i.e. a vegetation stress not related to the presence of oil) (Arellano et al. 2015, Noomen et al. 2012, van der Werff et al. 2008, Wang et al. 2018). As pointed out by authors, a better knowledge about the spectral response of vegetation to TPH and HM exposure is necessary for improving the detection. In that sense, studies carried out under controlled conditions may help to better identify the factors influencing this response.

The sensitivity of species to TPH and HM exposure is among the most influential factors (Merkl et al. 2005, Pérez-Hernández et al. 2017), as it leads to an important interspecific variability of vegetation spectral response (Arellano et al. 2017, Credoz et al. 2016, Emengini et al. 2013c, Sanches et al. 2013b). Hence, the less a species is sensitive to TPH and HM, the harder it is to detect oil contamination. But even when considering a sensitive species, several sources of variability compromise the detection. For instance, the presence of other stressors that induce almost similar effects to TPH and HM (e.g. water-deficit) induce false alarms (Emengini et al. 2013b, Lassalle et al. 2018). Likewise, the study scale (leaf, plant or canopy) strongly influences the spectral response (Emengini et al. 2013b, Sanches et al. 2013a). Contrasted spectral signatures of a single species exposed to TPH and HM mixtures appear in the nearinfrared (NIR) when measured at different scales (Sanches et al. 2013a). The composition and overall concentration of oil products also contribute to the response of vegetation, but have been rarely studied (Emengini et al. 2013a, Rosso et al. 2005, Sanches et al. 2013a). However, they are of great importance, because they vary substantially among regions and contexts (natural oil seeps, pipelines, production mud pits, etc.) (Adeniyi \& Afolabi 2002, Credoz et al. 2016, Metwally et al. 1997). In a perspective of airborne and satellite applications, it is therefore essential to account for all these factors under controlled conditions by reproducing as faithfully as possible the contexts of oil exposure encountered under natural conditions. 
This study focuses on the detection of various oil products, with the aim to distinguish among them from the spectral signature of shrubby temperate vegetation, under controlled conditions. Their discrimination with a water deficit stress, which is very common under natural conditions, was also investigated. A particular attention has been given to the biochemical response of the species, and its consequences on reflectance at three scales of measurement. A concrete case of field application is also presented for validating the approach.

2. Materials and Methods

2.1. Study site and species

An experiment was carried out for 32 days at the Pôle d'Etudes et de Recherche de Lacq (Platform for Experimental Research in Lacq (PERL), France), to study the biochemical and spectral responses of vegetation to various TPH and HM contaminations under controlled conditions. This experiment consisted in reproducing under greenhouse the conditions of a realistic case of oil contamination. For this purpose, an industrial brownfield located in temperate region, also known as "mud pit", was identified. The site served as a deposit of oil and gas production residues for a long time and is now contaminated by TPH and HM. The soil consists in two layers, made of muddy residues at the bottom, covered by a clayed coat at the surface. This brownfield has been colonized by vegetation, mainly Rubus fruticosus L. (bramble). The greenhouse experiment focused on this species, which is typically encountered on industrial sites under temperate climate (Credoz et al. 2016, Pini et al. 2009, Nujkić et al. 2016).

\subsection{Plant materials and treatments}


The greenhouse experiment consisted in six treatments applied to bramble, including four different mixtures of TPH and HM (Tab. 1). Wild plants of bramble were sampled from an uncontaminated site and acclimated in their soil of origin for 15 days under greenhouse. All the plants reached $15 \mathrm{~cm}$-height before the study began. Both soil layers from the brownfield were collected and used for the treatments applied to brambles. An uncontaminated soil was also sampled and has been analyzed to ensure similar texture than that of the brownfield. All the soils were sieved to $10 \mathrm{~mm}$ to remove residual roots and homogenized manually.

Bramble plants were exposed to six treatments, including four different mixtures of TPH and HM (Tab. 1). The first one (Clay) was made of 100\% clayed layer from the brownfield. This soil also contained various heavy metals known for their phytotoxicity (Nagajyoti et al. 2010). Two other treatments were made of muddy residues (Mud_B) or "Dahlia" crude oil (Crude) diluted in an uncontaminated soil. All these treatments exhibited similar $\mathrm{C}_{10}-\mathrm{C}_{40} \mathrm{TPH}$ concentrations (25000 mg. $\mathrm{kg}^{-1}$ ), but differed from each other by their composition in other contaminants. A fourth contaminated treatment (Mud_A) was applied to the plants. This involved muddy residues diluted to $6000 \mathrm{mg} \cdot \mathrm{kg}^{-1} \mathrm{C}_{10}-\mathrm{C}_{40} \mathrm{TPH}$. The remaining treatments consisted in $100 \%$ uncontaminated soil, with (Control) or without (Water_str) water supply. 
Table 1 Composition of soil treatments used in this study. Concentrations are given in mg.kg-1 Polycyclic Aromatic Hydrocarbons (PAH) represent the 16 priority pollutants of the U.S. Environmental Protection Agency (EPA 2014). (< DL: below detection limit.). Only low concentrations of HM were found in the uncontaminated soil (Control and Water-str) and corresponded to the local geochemical background.

\begin{tabular}{|c|c|c|c|c|c|}
\hline \multirow[b]{2}{*}{ Origin of oil mixture } & Control Water-str & \multirow{2}{*}{$\begin{array}{c}\text { Clay } \\
\text { Brownfield } \\
\text { (clay) }\end{array}$} & \multicolumn{2}{|c|}{ Mud_A Mud_B } & \multirow{2}{*}{$\begin{array}{c}\text { Crude } \\
\text { "Dahlia" crude oil }\end{array}$} \\
\hline & None & & \multicolumn{2}{|c|}{$\begin{array}{c}\text { Brownfield } \\
\text { (muddy residues) }\end{array}$} & \\
\hline \multicolumn{6}{|l|}{ Heavy metals: } \\
\hline arsenic & 7.5 & 22 & 12 & 14 & 12 \\
\hline cadmium & $<\mathrm{DL}$ & 1.7 & 0.20 & 0.67 & $<\mathrm{DL}$ \\
\hline chromium & 23 & 2000 & 74 & 310 & 30 \\
\hline copper & 4.5 & 73 & 9.9 & 17 & 9.1 \\
\hline mercury & $<\mathrm{DL}$ & 11 & 0.14 & 0.72 & 0.05 \\
\hline lead & 38 & 92 & 43 & 40 & 33 \\
\hline nickel & 12 & 61 & 15 & 18 & 14 \\
\hline zinc & 28 & 4000 & 170 & 660 & 57 \\
\hline Polycyclic Aromatic Hydrocarbons & $<\mathrm{DL}$ & 19 & 63 & 260 & 25 \\
\hline \multicolumn{6}{|l|}{ Total petroleum hydrocarbons: } \\
\hline $\mathrm{C}_{5}-\mathrm{C}_{10}$ & $<\mathrm{DL}$ & $<\mathrm{DL}$ & 52 & 200 & 4000 \\
\hline $\mathrm{C}_{10}-\mathrm{C}_{40}$ & $<\mathrm{DL}$ & 25000 & 6000 & 25000 & 25000 \\
\hline
\end{tabular}

Bramble roots were cleaned with water before transplanting in individual black pots filled with a 3-cm height layer of clay balls and $3 \mathrm{~L}$ of the corresponding treatment soil. 13 plant replicates were used for each treatment. They were grown between April and May at $27^{\circ} \mathrm{C}$ and $60 \%$ hygrometry, under natural and artificial light providing a 12:12 light:dark photoperiod. All the plants were fertilized weekly (N-K-P: 6-6-6) and irrigated to field capacity on a daily basis, except those subject to water-deficit (Water_str) which were not watered during the study. 


\subsection{Biochemical analysis}

The biochemical response of plants to the treatments was analyzed during the experiment. For this purpose, three leaves were sampled per treatment, on which two 15-mm wide disks were collected. The first one was used to determine leaf fresh (FW) and dry (DW) weights, leaf water content (LWC) and equivalent water thickness (EWT) (Arellano et al. 2015, Ceccato et al. 2001, Yilmaz et al. 2008). Leaf pigments were extracted in methanol from the second disk using the protocol of Diepens et al. (2017) and analyzed by High Pressure Liquid Chromatography (HPLC) according to the method described by Barlow et al. (1997). Analyses included chlorophyll a, b and various carotenoids. LWC, EWT and pigment content were examined together through Principal Component Analysis (PCA) (Hotelling 1933, Pearson 1901). The importance of the different variables was identified from their contribution to the main components (Jolliffe 2002). In addition, the spectral signatures of all disks were measured using the protocol described for leaves in section 2.4. and linked to LWC, EWT and pigment content for further analysis described in section 2.5. Biochemical analyses were performed at intermediate stages (days 11 and 18) and at the end of the experiment (day 32). No leaf was sampled during early stages to avoid influencing plant growth. 


\subsection{Spectral reflectance measurements and preprocessing}

The spectral signatures of the species were measured using an ASD FieldSpec 4 Hi-Res spectroradiometer (Analytical Spectral Device Inc. Boulder, Colorado, USA), with a spectral range of 350 to $2500 \mathrm{~nm}$. Data were acquired in radiance and converted to reflectance from the formula of Milton (1987), using a white reference calibration panel (Spectralon, Labsphere Inc., North Sutton, USA). Measurements were performed at leaf, plant and multi-plant scales ${ }^{1}$, from early (day 4) to intermediate (days 11 and 18) stages and at the end of the experiment (day 32). Leaf reflectance was measured using a leaf-clip with an internal light source. For each of the six treatments, the measurements were made on 3 young leaves per replicate $(n=234$ measurements per date). For each leaf, 5 consecutive spectral signatures were acquired and averaged to obtain a single one.

Additional measurements were carried out with a $10^{\circ}$-FOV fore-optic placed above the pots, providing a corresponding acquisition footprint of 5 and $20 \mathrm{~cm}$ at plant and multi-plant scales, respectively. Measurements were performed under natural light between $11.30 \mathrm{am}$. and $1.30 \mathrm{pm}$., in the absence of clouds. The reflectance of each replicate was thus measured at plant scale $(\mathrm{n}=$ 78 measurements per date). Four replicates of the same treatment were joined for measurements at multi-plant scale. The operation was repeated three times for each treatment, with different replicates $(n=18$ measurements per date). 10 consecutive spectral signatures were acquired per measurement at plant and multi-plant scales and averaged to obtain a single one.

Reflectance data located below 400 and above $2400 \mathrm{~nm}$ were removed at all acquisition scales, because of a low signal-to-noise ratio (SNR). Likewise, we did not conserve those from the 1350-1450 and 1800-1950 intervals due to low atmospheric transmission at plant and multi-plant

\footnotetext{
${ }^{1}$ In this study, the term "canopy scale" was restricted to in situ measurements to avoid confusions.
} 
scales. At all acquisition scales, a Savitzky-Golay smoothing filter with a second order polynomial and a seven-point window was then applied to the spectral signatures to improve the SNR at the remaining wavelengths (Gomez et al. 2008, Savitzky \& Golay 1964).

\subsection{Vegetation indices}

In order to catch similarities among acquisition scales, 33 simple and normalized vegetation indices (VI) were computed and used in a three-steps approach. These indices are presented in Table 2. The first step consisted in identifying which biochemical parameters (pigments, LWC and EWT) were responsible for index changes among treatments (Fig. 1). This was achieved by regression using the leaves sampled for biochemical analysis. A strong multicollinearity was detected among pigments by calculating Variance Inflation Factor (VIF $>10$ ) (Belsley et al. 1980). Multicollinearity occurs when predictors (i.e. pigments, LWC, EWT) are linear combination of each other, and leads to confusions when identifying those contributing most to the response variable (i.e. VI) (Dormann et al. 2013). To prevent such consequence, we used the elastic net regression (Zou \& Hastie 2005), a penalized least squared method allowing efficient predictor selection under multicollinearity (Chakraborty et al. 2017). The elastic net regression was performed on each VI. Their best set of predictors and the resulting $\mathrm{R}^{2}$ of the model are presented.

Once we linked VI to biochemical parameters, we tested for their ability to discriminate among treatments, at all acquisition scales. The $33 \mathrm{VI}$ were computed from the spectral signatures acquired on (unsampled) leaves, plants and multi-plants. The second step of the approach consisted in detecting similarities in VI among acquisition scales, through the ranking of treatments. This was achieved for each VI using Kendall's coefficient of concordance (W) 
(Kendall \& Smith 1939) based on VI values of treatments at day 32, as it was the most representative of a long-term exposure of vegetation in our study. Kendall's W evaluates the degree of agreement of treatment ranking among acquisition scales for a given VI and is tested for significance using a 1000-fold permutation test (Elger \& Barrat-Segretain 2004, Legendre 2005). As a result, we only retained VI with best elastic net results $\left(\mathrm{R}^{2}>0.7\right)$ and high significant concordance $(\mathrm{W}>0.75, \mathrm{p}<0.05)$, thus expressing changes in pigment and water content resulting from treatment exposure at leaf, plant and multi-plant scales (Fig. 1). The selected VI were finally tested to discriminate among treatments using $\mathrm{L}^{2}$-Regularized Logistic Regression (RLR), also known as Ridge regression (Friedman \& Popescu 2004, Hoerl \& Kennard 1970). RLR has been widely used for classification purposes in various domains including remote sensing (Tuia et al. 2016, Zhang et al. 2015), and revealed to be efficient when applied on vegetation (Erudel et al. 2017). We only trained the RLR classifier at leaf scale to assess the robustness of VI at higher acquisition scales. For this purpose, half of the leaf dataset was used for training, and the remaining half as test set. In addition, the entire plant and multiplant datasets were used to test the method. The classification was carried out on each date separately and iterated 30 times. The overall quality of predictions was evaluated by Mean Overall Accuracy (MOA) and mean Cohen's Kappa coefficient (Erudel et al. 2017, Wei et al. 2017). Confusion matrices are also presented to illustrate the results. These matrices were obtained by comparing the predicted treatments to the true ones, and thus allowed identifying the confusions among treatments. User's and Producer's accuracies (UA and PA, respectively) were also computed as described in Story \& Congalton (1986). UA indicates the probability for a sample being classified in a given treatment, to actually correspond to this treatment, whereas PA indicates the probability of a sample from this treatment to be correctly classified. All data 
analyses were performed under Python language using Statsmodels (Seabold \& Perktold 2010), Scipy (Oliphant 2007) and Scikit-Learn (Pedregosa et al. 2011) libraries. 
Table 2 Vegetation indices used in this study (R: Reflectance, D: First derivative).

Index

Formula

Reference

Chlorophyll Absorption Ratio Index

Chlorophyll/Carotenoids Index

Carter Index 1

Carter Index 2

Gitelson \& Merzlyak Index 1

Gitelson \& Merzlyak Index 2

Lichtenthaler Index 1

Lichtenthaler Index 2

Lichtenthaler Index 3

modified Chlorophyll Absorption Ratio Index 1

modified Chlorophyll Absorption Ratio Index 2

modified Simple Ratio $705 \mathrm{~nm}$

MERIS Terrestrial Chlorophyll Index

Normalized Difference $705 \mathrm{~nm}$

Normalized Pigment Chlorophyll Index

Optimized Soil-Adjusted Vegetation Index

Photochemical Reflectance Index 1

Photochemical Reflectance Index 2

Photochemical Reflectance Index 3

Plant Senescence Reflectance Index

Pigment Specific Simple Ratio a

Pigment Specific Simple Ratio b

Pigment Specific Simple Ratio c

Structure Intensive Pigment Index 1

Structure Intensive Pigment Index 2

Structure Intensive Pigment Index 3

Simple Ratio 705 nm

Transformed CARI

Transformed CARI / OSAVI

Vogelmann Index 1

Vogelmann Index 2

Vogelmann Index 3

Disease Water Stress Index
CARI $=\mathrm{R}_{700}\left|\mathrm{R}_{670} \mathrm{a}+\mathrm{R}_{670}+\mathrm{b}\right| / \mathrm{R}_{670}\left(\mathrm{a}^{2}+1\right)^{0.5}$

with $\mathrm{a}=\left(\mathrm{R}_{700}-\mathrm{R}_{550}\right) / 150$ and $\mathrm{b}=\mathrm{R}_{550}-\mathrm{R}_{550} \mathrm{a}$

$\mathrm{CCI}=\mathrm{D}_{720} / \mathrm{D}_{700}$

CTR1 $=\mathrm{R}_{695} / \mathrm{R}_{420}$

$\mathrm{CTR} 2=\mathrm{R}_{695} / \mathrm{R}_{760}$

$\mathrm{GM} 1=\mathrm{R}_{750} / \mathrm{R}_{550}$

$\mathrm{GM} 2=\mathrm{R}_{750} / \mathrm{R}_{700}$

$\mathrm{LI} 1=\left(\mathrm{R}_{800}-\mathrm{R}_{680}\right) /\left(\mathrm{R}_{800}+\mathrm{R}_{680}\right)$

$\mathrm{LI} 2=\mathrm{R}_{440} / \mathrm{R}_{690}$

$\mathrm{LI} 3=\mathrm{R}_{440} / \mathrm{R}_{740}$

mCARI $1=1.2\left[2.5\left(R_{800}-R_{670}\right)-1.3\left(R_{800}-R_{550}\right)\right]$

mCARI2 $=\frac{1.5\left[2.5\left(R_{800}-R_{670}\right)-1.3\left(R_{800}-R_{550}\right)\right]}{\sqrt{\left(2 R_{800}+1\right)^{2}-\left(6 R_{800}-5 \sqrt{R_{670}}-0.5\right.}}$

mSR705 $=\left(\mathrm{R}_{750}-\mathrm{R}_{445}\right) /\left(\mathrm{R}_{750}+\mathrm{R}_{445}\right)$

MTCI $=\left(R_{754}-R_{709}\right) /\left(R_{709}+R_{681}\right)$

ND705 or NDVI705 $=\left(\mathrm{R}_{750}-\mathrm{R}_{705}\right) /\left(\mathrm{R}_{750}+\mathrm{R}_{705}\right)$

$\mathrm{NPCI}=\left(\mathrm{R}_{680}-\mathrm{R}_{430}\right) /\left(\mathrm{R}_{680}+\mathrm{R}_{430}\right)$

OSAVI $=(1+0.16)\left(R_{800}-R_{670}\right) /\left(R_{800}+R_{670}+0.16\right)$

PRI1 $=\left(R_{528}-R_{567}\right) /\left(R_{528}+R_{567}\right)$

PRI2 $=\left(R_{531}-R_{570}\right) /\left(R_{531}+R_{570}\right)$

PRI3 $=\left(R_{570}-R_{539}\right) /\left(R_{570}+R_{539}\right)$

PSRI $=\left(\mathrm{R}_{678}-\mathrm{R}_{500}\right) / \mathrm{R}_{750}$

PSSRa $=\mathrm{R}_{800} / \mathrm{R}_{680}$

PSSRb $=R_{800} / R_{635}$

PSSRc $=\mathrm{R}_{800} / \mathrm{R}_{470}$

SIPI1 $=\left(\mathrm{R}_{800}-\mathrm{R}_{445}\right) /\left(\mathrm{R}_{800}+\mathrm{R}_{680}\right)$

SIPI2 $=\left(\mathrm{R}_{800}-\mathrm{R}_{505}\right) /\left(\mathrm{R}_{800}+\mathrm{R}_{690}\right)$

SIPI3 $=\left(R_{800}-R_{470}\right) /\left(R_{800}+R_{680}\right)$

$\mathrm{SR705}=\mathrm{R}_{750} / \mathrm{R}_{705}$

TCARI $=3\left[\left(\mathrm{R}_{700}-\mathrm{R}_{670}\right)-0.2\left(\mathrm{R}_{700}-\mathrm{R}_{550}\right)\left(\mathrm{R}_{700} / \mathrm{R}_{670}\right)\right]$

$\frac{\text { TCARI }}{\text { OSAVI }}=\frac{3\left[\left(\mathrm{R}_{700}-\mathrm{R}_{670}\right)-0.2\left(\mathrm{R}_{700}-\mathrm{R}_{550}\right)\left(\mathrm{R}_{700} / \mathrm{R}_{670}\right)\right]}{(1+0.16)\left(\mathrm{R}_{800}-\mathrm{R}_{670}\right) /\left(\mathrm{R}_{800}+\mathrm{R}_{670}+0.16\right)}$

VOG1 $=\mathrm{R}_{740} / \mathrm{R}_{720}$

VOG2 $=\left(\mathrm{R}_{734}-\mathrm{R}_{747}\right) /\left(\mathrm{R}_{715}+\mathrm{R}_{726}\right)$

VOG3 $=\left(\mathrm{R}_{734}-\mathrm{R}_{747}\right) /\left(\mathrm{R}_{715}+\mathrm{R}_{720}\right)$

DWSI $=\left(R_{800}-R_{550}\right) /\left(R_{1660}+R_{680}\right)$
Kim et al. 1994

Sims et al. 2006

Carter et al. 1994

Carter et al. 1994

Gitelson \& Merzlyak 1997

Gitelson \& Merzlyak 1997

Lichtenthaler et al. 1996

Lichtenthaler et al. 1996

Lichtenthaler et al. 1996

Haboudane et al. 2004

Haboudane et al. 2004

Sims \& Gamon 2002

Dash \& Curan 2007

Sims \& Gamon 2002

Peñuelas et al. 1994

Rondeaux et al. 1996

Gamon et al. 1992

Gamon et al. 1992

Gamon et al. 1992

Merzlyak et al. 1999

Blackburn 1998a

Blackburn 1998a

Blackburn 1998a

Blackburn 1998b

Blackburn 1998b

Blackburn 1998b

Sims \& Gamon 2002

Haboudane et al. 2002

Haboudane et al. 2002

Vogelmann et al. 1993

Zarco-Tejada et al. 2001

Zarco-Tejada et al. 2001

Apan et al. 2004 


\subsection{Field validation}

In order to validate the approach under natural conditions, additional measurements were performed on brambles directly on both the brownfield and on uncontaminated sites. For this purpose, 30 patches were identified on the brownfield. Their soil was analyzed and showed similar TPH and HM concentrations to those of the Clay treatment from the experiment. 30 other patches from five natural sites were also identified. These sites were located a few kilometers away from the brownfield and had never been subject to industrial activities. They were considered as controls, because no contaminant was found in their soil. The spectral signatures of all patches were collected at canopy scale in June, under the same conditions of acquisition as those of multi-plant scale during the experiment (11.30 am. -1.30 pm., 20-cm radiance acquisition footprint). VI were computed and tested with the RLR classifier (Fig. 1), following training on the leaf dataset from the greenhouse experiment exclusively. 


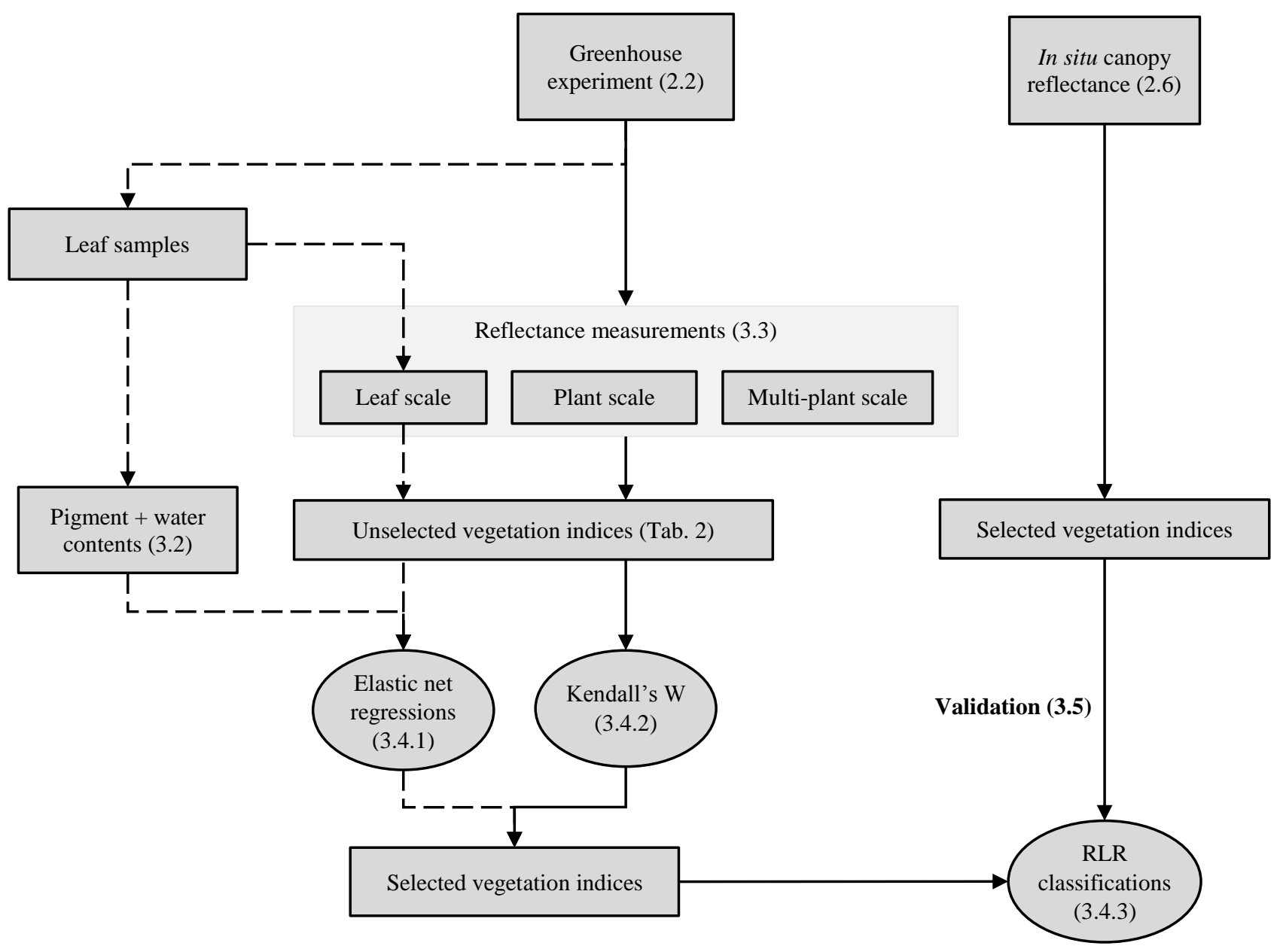

Figure 1 Flowchart of the approach using vegetation indices presented in this study. Sections and tables associated to the different steps are specified in brackets. The dotted line indicates the steps carried out at leaf scale only. 
3. Results and Discussion

3.1. Visible symptoms

Visible symptoms of leaf discoloration appeared on all plants exposed to TPH and HM mixtures and to water-deficit after 18 days of experiment (Fig. 2). Commonly described as chlorosis, these symptoms have been frequently observed on plant species exposed to crude oil or refined products (Athar et al. 2016, Baruah et al. 2014, Rosso et al. 2005) and various HM such as Ni, Pb and Zn (Nagajyoti et al. 2010), including Rubus fruticosus (Dorrington \& Pyatt 1983, Lassalle et al. 2018). In our study, it was particularly pronounced for plants exposed to crude oil or muddy residues. The latter also exhibited a singular red pigmentation on leaf margin, along with symmetric interveinal marks on leaf adaxial face at highest concentrations (Mud_B) (Fig. 2). No similar symptom has already been described in previous experiments involving TPH and HM. However, several authors noticed that brambles are able to accumulate HM in leaves (Dorrington \& Pyatt 1983, Nujkić et al. 2016, Yoon et al. 2006). Hence, the observed symptoms may be linked to HM toxicity (Hagemeyer 1999, Kvesitadze et al. 2006). All these symptoms were associated to a reduced plant growth when compared to Control. Plants undergoing waterdeficit also showed a drooping habit, which is typically observed in those conditions (Percival et al. 1998). On day 32, substantial evolutions appeared on plants from the Mud_A and Clay treatments. No or very few symptoms were observed on newly appeared leaves from these treatments and plant development was similar to that of the Control (Fig. 2). None of the plants exposed to any of the TPH and HM mixtures died during the experiment. This tolerance of bramble to oil contamination explains its marked presence on industrial brownfields in temperate regions. 


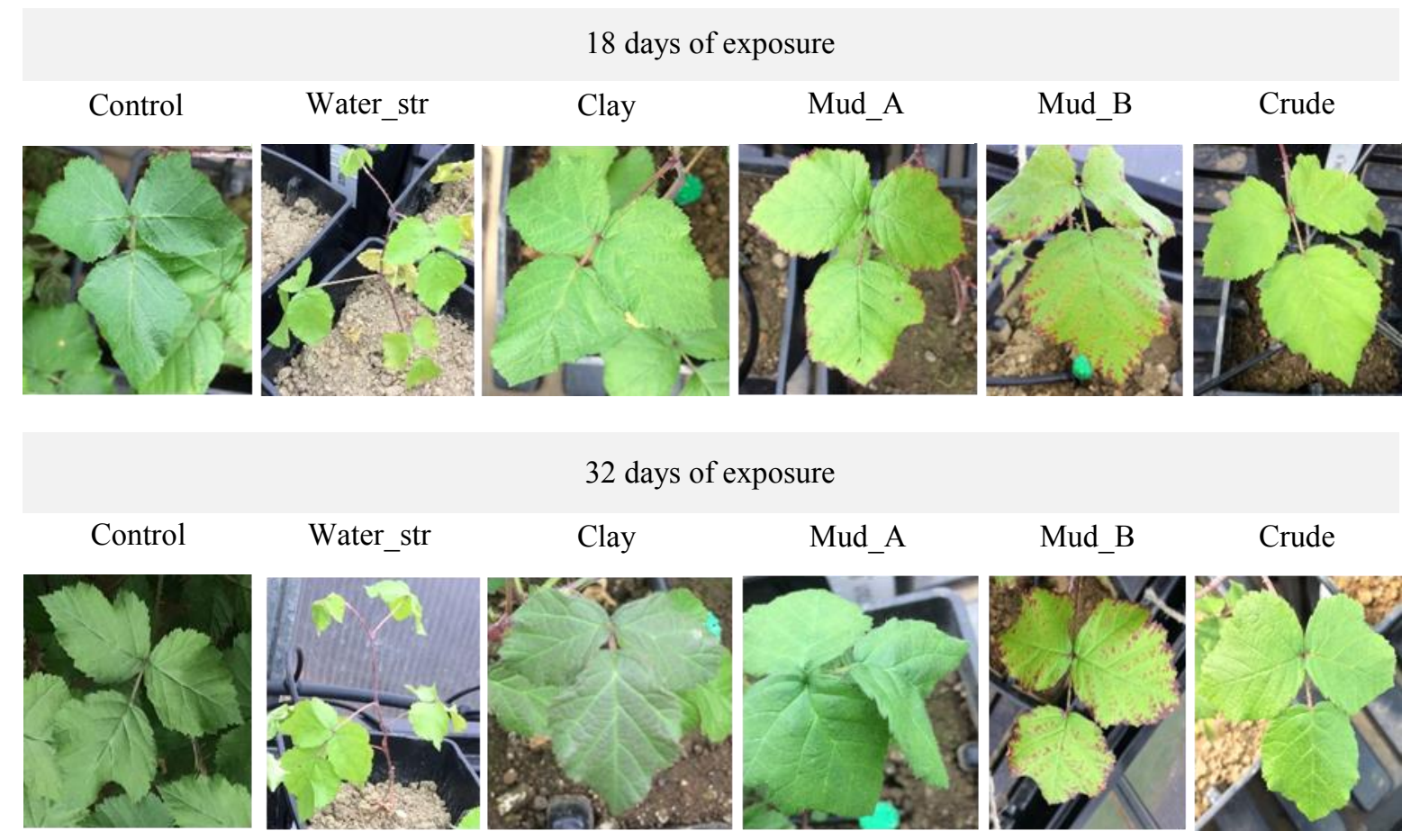

Figure 2 Visible symptoms observed on Rubus fruticosus (bramble) leaves after 18 and 32 days of exposure to the treatments (see section 2.2 for further information about the treatments). These symptoms were confirmed later by biochemical analyses described in section 3.2.

\subsection{Biochemical responses to the treatments}

The PCA performed on biochemical analyses of sampled leaves confirmed the differentiated effects of TPH and HM mixtures on plants. Most of biochemical parameters were positively correlated to the first Principal Component (PC1) (Fig. 3a), with major contribution of chlorophylls and carotenoids. Antheraxanthin and zeaxanthin were the only pigments contributing to PC2. As PC1 explained most of the variability (72\%), we focused on the temporal evolution of plant treatments along this axis. Results indicated no difference after 11 days of exposure (Fig. 3b). However, significant changes appeared on day 18, thus reflecting stress symptoms described in section 3.1. Control plants moved toward positive PC1 values, 
indicating an increase in pigment and water contents resulting from healthy plant growth. All other treatments remained close to the initial axis values. Plants exhibiting pronounced symptoms (Crude, Mud_B and Water_str) slightly moved toward negative PC1 values, as their pigment and water contents began to decrease. This was confirmed at the end of the study (day 32), with an opposite trajectory compared to Control. In contrast, the disappearance of stress symptoms on Mud_A- and Clay-exposed plants on day 32 reflected an increase of pigment and water contents, expressed by positive $\mathrm{PC} 1$ values. 

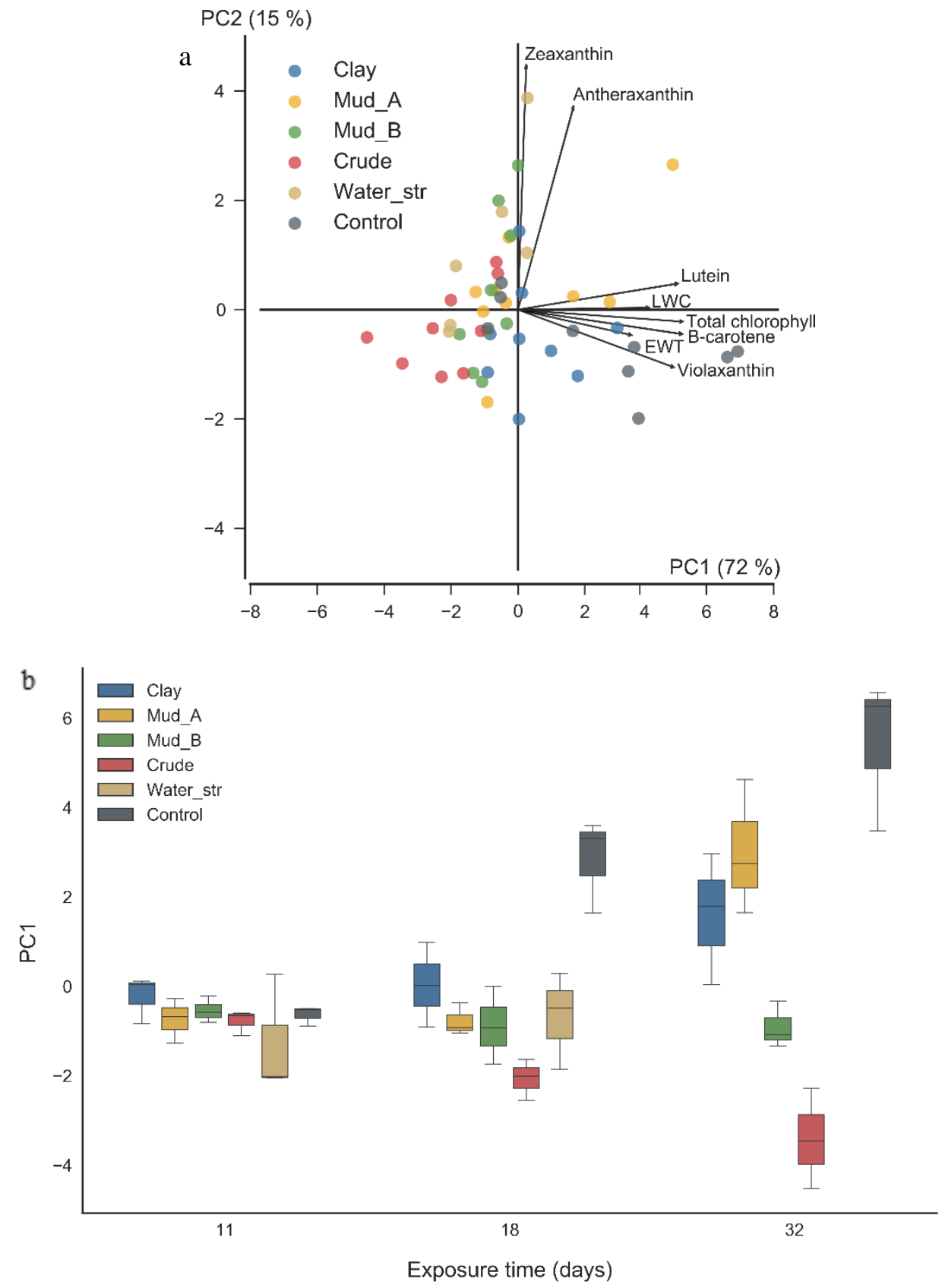

Figure 3 (a) PCA performed on pigment and water content data from three dates (days 11, 18 and 32, $\mathrm{n}=51)$. The first two Principal Components $(\mathrm{PC})$ are represented. Correlations between each variable and PC are represented by annotated arrows. The length of the arrows was multiplied by five on each PC for graphical convenience. (b) Temporal evolution of treatments along the first principal component (PC1), from day 11 to 32 . 
Alterations of pigment and water contents are frequently observed under TPH and HM exposure, alone or in mixture (Balliana et al. 2017, Baruah et al. 2014, Garg \& Singla 2011, Shanker et al. 2005). They might be due to modifications of soil physico-chemical and biological properties (Dindar et al. 2015, Khamehchiyan et al. 2007, Kisic et al. 2009), which lead to decreasing nutrient and water availability for plants (Nie et al. 2011, Athar et al. 2016). PAH, TPH and HM can penetrate plant tissues and affect plant water status and photosynthetic capacity (Athar et al. 2016, Barceló \& Poschenrieder 1990, Emengini et al. 2013b, Nagajyoti et al. 2010). However, their uptake by plant roots strongly varies with their chemical properties and association in mixtures (Kvesitadze et al. 2006, Nie et al. 2010, Semple et al. 2003). For example, low-carbon $\mathrm{PAH}$ and $\mathrm{C}_{5}-\mathrm{C}_{10} \mathrm{TPH}$ penetrate roots more easily than larger chemical compounds (Su \& Zhu 2008, Tao et al. 2004), so they might be main responsible for biochemical alterations in our study. HM were also probably involved, since their bioavailability is enhanced in the presence of TPH (Barceló \& Poschenrieder 1990, Nagajyoti et al. 2010, Nie et al. 2010). Judging by the evolution of Mud_A- and Clay-exposed plants, the effects of $\mathrm{C}_{5}-\mathrm{C}_{10}$ TPH and HM are however reversible at low concentrations, thanks to detoxification mechanisms (Kvesitadze et al. 2006, Parrish et al. 2006).

None of the Control and contaminated treatments followed a clear trajectory on PC2. However, a noticeable evolution of water-deficient plants toward positive values appeared along this axis on day 18 , indicating a peak of antheraxanthin and zeaxanthin. These pigments have already been reported as affected by TPH and HM exposure for the same species (Lassalle et al. 2017). Their increase is however closely involved in plant response to water stress through the 
activation of the xanthophyll cycle (Alonso et al. 2001, Galmés et al. 2007, Shvaleva et al. 2006). This demonstrates differentiated effects of these two stressors on plant biochemistry.

\subsection{Reflectance modifications}

The spectral signatures of brambles were consistent with their biochemical response (Fig. 4ac). No difference appeared among treatments on days 4 and 11, and the spectral signatures were representative of healthy vegetation at all acquisition scales. These signatures were characterized by a low reflectance in the VIS with a peak around $550 \mathrm{~nm}$, followed by a plateau in the NIR, and two marked peaks in the SWIR around 1650 and $2200 \mathrm{~nm}$. On day 18, several reflectance changes appeared for brambles exposed to TPH and HM mixtures or to water deficit. Compared to Control, they showed an increase of reflectance in the VIS, which is consistent with previous studies (Credoz et al. 2016, Emengini et al. 2013a, Rosso et al. 2005, Sanches et al. 2013a). The affected wavelengths corresponded to those of chlorophyll and carotenoid absorption (Zhang et al. 2017). This increase was more pronounced on Crude, Mud_B and Water_str treatments, which shows that the spectral response intensity was in accordance to that of the biochemical response. Such changes in reflectance are commonly observed on stressed vegetation (Rosso et al. 2005, Smith et al. 2005, Stimson et al. 2005). However, because brambles are naturally tolerant to stressful conditions, their response to TPH and HM remained less pronounced than that of other species found in similar studies, especially crops (Emengini et al. 2013a, Credoz et al. 2016, Sanches et al. 2013a). The most important differences among acquisition scales appeared in the NIR and short-wave infrared (SWIR). Because of reduced leaf density and ground cover (Asner 1998, Asner \& Martin 2008), reflectance was lower than that of Control at plant and multi-plant scales in the NIR. This response was however not observed on leaf 
reflectance, which is mostly dependent on leaf anatomy in this region of the spectrum (Slaton et al. 2001). These results are consistent with those described in similar studies (Sanches et al. 2013a, Zhu et al. 2014). In the short-wave infrared (SWIR), reflectance was also affected by biochemical alterations at leaf scale and by reduced ground cover at plant and multi-plant scales when compared to that of Control. 

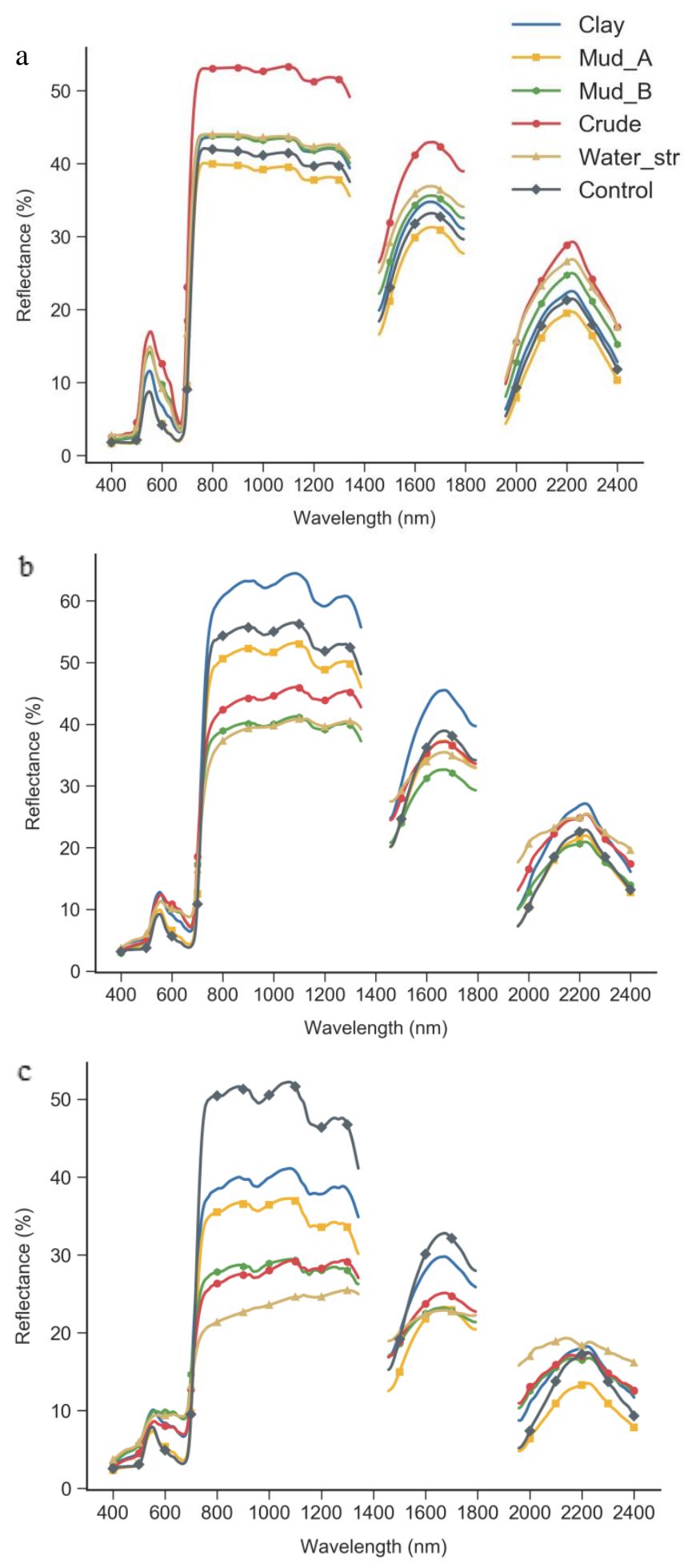

Figure 4 Mean spectral signatures of Rubus fruticosus (bramble) measured after 32 days of exposure to the treatments at (a) leaf, (b) plant and (c) multi-plant scales. Reflectance data 
located in the 1350-1450 and 1800-1950 intervals were removed, because of significant atmospheric effects at plant and multi-plant scales.

After 32 days, important changes occurred among treatments. Brambles growing on Mud_B and Crude soils exhibited lower pigment content (Fig. 3b), so leaf reflectance continued to increase in the VIS (Fig. 4a). In contrast, the late pigment increase of brambles exposed to Clay and Mud_A treatments induced a reduction of reflectance in the VIS, compared to day 18. As a result, the spectral signatures of Mud_A became closely similar to Control in this region, at all acquisition scales. The late growth of brambles also modified plant and multi-plant reflectance. Plant reflectance from the Clay treatment exceeded that of Control in the NIR (Fig. 4b), which confirmed previous results obtained with similar TPH and HM mixtures (Lassalle et al. 2018). Such changes were however not observed at multi-plant scale (Fig. 4c), since ground cover was still limited. On the same date, brambles from other treatments remained severely impacted in the NIR and the SWIR, especially those exposed to the Crude treatment. A similar response was observed on Brachiaria brizantha H.S. exposed to $10 \mathrm{~L} . \mathrm{m}^{-3}$ gasoline spill in a previous study (Sanches et al. 2013a). In addition, this treatment induced an important increase of reflectance in the NIR and SWIR at leaf scale, which might be related to the strong alterations of leaf anatomy and water content specifically induced by this mixture (Baruah et al. 2014).

\subsection{Vegetation indices}

\subsubsection{Relationship between biochemical and spectral responses}

Regressions performed on each VI from leaf samples led to the identification of at least one contributing pigment (Tab. 3), except for the DWSI which was only correlated to LWC. From 
the 33 indices, 15 were retained after this step $\left(\mathrm{R}^{2}>0.7\right)$. For almost all VI, variations were mainly explained by total chlorophylls $(a+b), \beta$-carotene and lutein, which were implicated in the biochemical response of brambles to the treatments (Fig. 3a). These results confirmed that VI are suitable for tracking changes in pigment and water contents resulting from TPH and HM exposure, as suggested by previous studies (Arellano et al. 2015, Lassalle et al. 2017). Other carotenoids were sometimes involved, especially antheraxanthin and zeaxanthin. Total carotenoid estimation has been widely assessed using VI, but only few studies attempted to separate carotenes and xanthophylls (Boelman et al. 2016, Stylinski et al. 2002). Our study showed that it is of great importance for understanding the biochemical and spectral responses of vegetation to TPH and HM exposure.

Table 3 Results of elastic net regressions and Kendall's W selection procedure obtained on vegetation indices. Biochemical parameters contributing to index variations are presented in order of importance, along with the resulting $\mathrm{R}^{2}$. (Chl: Total chlorophylls, Lut: Lutein, B-car: $\beta$ carotene, Ant: Antheraxanthin, Zea: Zeaxanthin, Vio: Violaxanthin, LWC: Leaf Water Content.) Indices showing significant Kendall's W $(\mathrm{p}<0.05)$ are denoted by a*. Those retained for classifications $\left(\mathrm{R}^{2}>0.7, \mathrm{~W}>0.75^{*}\right)$ are marked bold.

\begin{tabular}{cccc} 
& \multicolumn{2}{c}{ Elastic net regression } & \\
\cline { 2 - 3 } Index & Pigments & $\mathrm{R}^{2}$ & \\
& & & \\
& & & \\
CARI & Chl, Lut & 0.77 & 0.29 \\
CCI & Chl, B-car & 0.94 & $0.92^{*}$ \\
CTR1 & Lut, Ant & 0.49 & $0.90^{*}$ \\
CTR2 & Chl, Lut & 0.87 & $0.90^{*}$ \\
GM1 & Chl, B-car & 0.90 & $0.94^{*}$ \\
GM2 & Chl, B-car & 0.93 & $0.90^{*}$
\end{tabular}




$\begin{array}{cccc}\text { LI1 } & \text { Chl } & 0.17 & 0.92^{*} \\ \text { LI2 } & \text { Chl, B-car, Zea } & 0.60 & 0.97^{*} \\ \text { LI3 } & \text { Lut, Ant } & 0.19 & 0.90^{*} \\ \text { MTCI } & \text { Chl, B-car } & 0.94 & 0.90^{*} \\ \text { ND705 } & \text { Chl, B-car } & 0.93 & 0.90^{*} \\ \text { NPCI } & \text { Lut, Ant } & 0.41 & 0.76^{*} \\ \text { OSAVI } & \text { Chl } & 0.23 & 0.97^{*} \\ \text { PRI1 } & \text { B-car, Vio } & 0.67 & 0.97^{*} \\ \text { PRI2 } & \text { Chl, B-car } & 0.82 & 0.92^{*} \\ \text { PRI3 } & \text { Lut, B-car } & 0.87 & 0.90^{*} \\ \text { PSRI } & \text { Chl, B-car } & 0.50 & 0.34 \\ \text { PSSRa } & \text { B-car, Zea, Vio } & 0.20 & 0.38 \\ \text { PSSRb } & \text { B-car, Zea, Vio } & 0.49 & 0.83^{*} \\ \text { PSSRc } & \text { B-car, Zea, Vio } & 0.28 & 0.64 \\ \text { SIPI1 } & \text { Lut, Ant } & 0.51 & 0.62 \\ \text { SIPI2 } & \text { Lut, Ant } & 0.75 & 0.92^{*} \\ \text { SIPI3 } & \text { Lut, Ant } & 0.45 & 0.62 \\ \text { SR705 } & \text { Chl, B-car } & 0.94 & 0.90^{*} \\ \text { TCARI } & \text { Lut, Zea } & 0.67 & 0.34 \\ \text { TCARI / OSAVI } & \text { Lut, Ant } & 0.08 & 0.23 \\ \text { VOG1 } & \text { Chl, B-car } & 0.22 & 0.58 \\ \text { VOG2 } & \text { Lut } & 0.93 & 0.90^{*} \\ \text { VOG3 } & \text { Lut } & 0.93 & 0.90^{*} \\ \text { mCARI1 } & \text { Lut, Ant } & 0.09 & 0.21 \\ \text { mCARI2 } & \text { Zea } & 0.39 & 0.31 \\ \text { mSR705 } & \text { Chl, B-car } & 0.92 & 0.90^{*} \\ \text { DWSI } & \text { LWC } & 0.84 & 0.85^{*} \\ & & & \end{array}$

\subsubsection{Concordance of VI among acquisition scales}

When applied to all spectral signatures, the same VI showed similarities among acquisition scales, despite differences described in section 3.3. Most of them exploited the VIS, which is suitable for tracking alterations of vegetation pigments at varying scales of measurement (Blackburn 1998, Daughtry et al. 2000, Garbulsky et al. 2011, Xiao et al. 2014). Based on treatment ranking at day 32, Kendall's W was significant and greater than 0.75 for 22 of the 33 VI, indicating good concordance among acquisition scales (Tab. 3). This included 14 out of the 
15 indices strongly linked to biochemical parameters $\left(R^{2}>0.7\right)$, which were selected for classifications. For most of the retained VI, treatments were arranged as follows. As expected, Mud_B, Crude and Water_str treatments often exhibited similar VI values, which corresponded to low pigment and water contents (Fig. 5). They were followed by Clay and Mud_A treatments, which values were close - and sometimes equal - to Control, because of pigment and growth recovery after 32 days. A lower variability was observed among replicates at multi-plant scale due to strong influence of bare soil fraction.

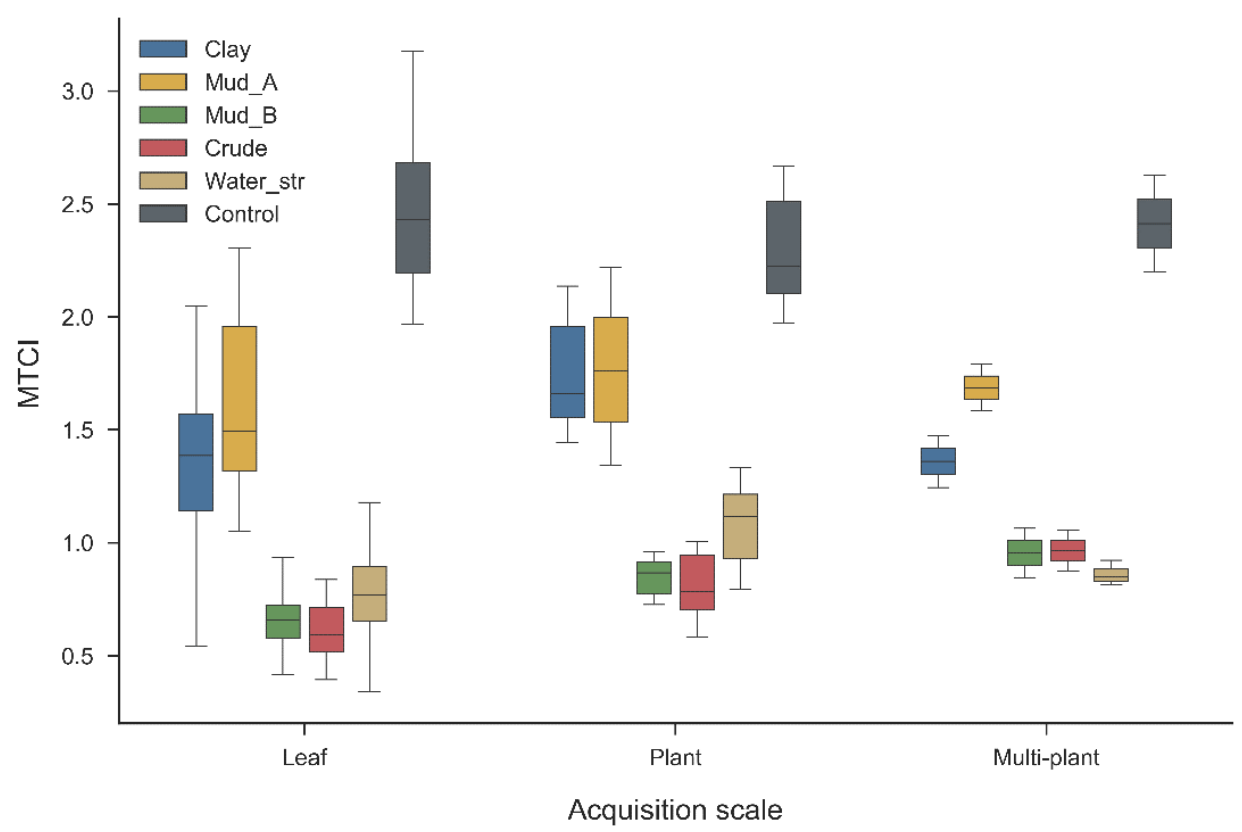

Figure 5 MTCI index computed from leaf, plant and multi-plant reflectance data acquired on day 32. This vegetation index was linked to total chlorophyll and $\beta$-carotene contents $\left(\mathrm{R}^{2}=0.94\right)$ and exhibited strong similarities among acquisition scales following Kendall's W selection procedure $(\mathrm{W}=0.90, \mathrm{p}<0.05)$.

3.4.3. Discrimination of treatments using VI 
RLR classifications performed on the 14 retained VI confirmed the concordance among acquisition scales. Same classifications using the original 33 VI led to worse results at day 18 and 32 and highlighted the improvements brought by the selection procedure (data not shown). Following training on half of leaf dataset exclusively, MOA and Kappa obtained from day 4 to day 32 on leaf, plant and multi-plant test sets were consistent with evolutions of spectral signatures. These results are summarized in Table 4. MOA and Kappa were significantly lower while increasing acquisition scale, since the alterations of leaf optical properties became more difficult to detect (Tab. 4). From day 4 to 11, MOA and Kappa stayed constant and lower than $40 \%$ and 0.4 , respectively, at all acquisition scales. On these dates, leaf biochemistry and plant development were similar among treatments, which explain the difficulty to discriminate among them. 
Table 4 Mean Overall Accuracy (MOA) and mean Cohen's Kappa ( \pm SD) obtained from RLR classifications performed on leaf, plant and multi-plant test sets with the 14 retained vegetation indices. The training step was exclusively performed at leaf scale using different samples on each of the 30 iterations. For each scale, significant differences of MOA and Kappa between dates are denoted by different superscript letters (t-test, $\mathrm{p}<0.05)$.

\begin{tabular}{cccccc} 
& \multicolumn{5}{c}{ Exposure time (days) } \\
\cline { 3 - 6 } Leaf & & 4 & 11 & 18 & 32 \\
\cline { 3 - 6 } & MOA & $36.3( \pm 5)^{\mathrm{a}}$ & $39.9( \pm 6)^{\mathrm{a}}$ & $70.8( \pm 3)^{\mathrm{b}}$ & $74( \pm 4)^{\mathrm{b}}$ \\
& Kappa & $0.30( \pm 0.06)^{\mathrm{a}}$ & $0.35( \pm 0.06)^{\mathrm{a}}$ & $0.65( \pm 0.04)^{\mathrm{b}}$ & $0.69( \pm 0.05)^{\mathrm{b}}$ \\
\hline \multirow{3}{*}{ Plant } & MOA & $26.8( \pm 6)^{\mathrm{a}}$ & $32.2( \pm 5)^{\mathrm{a}}$ & $61.8( \pm 7)^{\mathrm{b}}$ & $56.7( \pm 7)^{\mathrm{b}}$ \\
& Kappa & $0.13( \pm 0.07)^{\mathrm{a}}$ & $0.15( \pm 0.08)^{\mathrm{a}}$ & $0.54( \pm 0.09)^{\mathrm{b}}$ & $0.48( \pm 0.09)^{\mathrm{b}}$ \\
\hline \multirow{3}{*}{ Multi-plants } & MOA & $24.1( \pm 6)^{\mathrm{a}}$ & $28.9( \pm 4)^{\mathrm{a}}$ & $55.6( \pm 6)^{\mathrm{b}}$ & $51.7( \pm 5)^{\mathrm{b}}$ \\
& Kappa & $0.12( \pm 0.07)^{\mathrm{a}}$ & $0.14( \pm 0.06)^{\mathrm{a}}$ & $0.48( \pm 0.08)^{\mathrm{b}}$ & $0.42( \pm 0.06)^{\mathrm{b}}$
\end{tabular}

On day 18, MOA and Kappa became significantly higher than on previous dates. On this date, the levels of water and pigment alterations differed among the treatments (Fig. 3b). These alterations were caught by VI at all acquisition scales, which led to a better discrimination among the treatments compared to the previous dates (Tab. 5). Since all VI were not correlated to the same set of biochemical parameters (Tab. 3), they were complementary in classifications. No significant difference of MOA and Kappa was observed at any acquisition scale between day 18 and 32, which firstly suggested no evolution in treatment discrimination. However, confusion matrices indicated critical changes between the two dates. On day 18 , only few confusions were made between Control and other treatments at all acquisition scales $(\leq 5 \%)$, which agreed with biochemical and spectral responses (Tab. 5). Other treatments were however harder to discriminate among them, since their responses remained close on this date. Evolutions of VI values observed on Clay and Mud_A treatments toward those of Control then introduced 
confusions with the latter on day 32. More than $25 \%$ of Mud_A samples were thus incorrectly labeled as Control at all acquisition scales. As a consequence, classification accuracy of Control decreased between day 18 and 32, as the prolonged exposure time to Clay and Mud_A mixtures negatively affected their discrimination with Control. In contrast, it was benefit for discriminating the Control with other mixtures. Mud_B and Crude treatments were never confused with Control on this date and rarely with Clay and Mud_A treatments, at all acquisition scales. This was also the case of water-deficient plants. These impacting treatments remained however difficult to discriminate among them, because of close VI values (Fig. 5).

Table 5 Examples of relative confusion matrices (\%) obtained from RLR classifications performed on leaf and plant test sets at day 18 and 32, following training at leaf scale. UA and PA stand for User Accuracy and Producer Accuracy (\%), respectively.

18 days of exposure

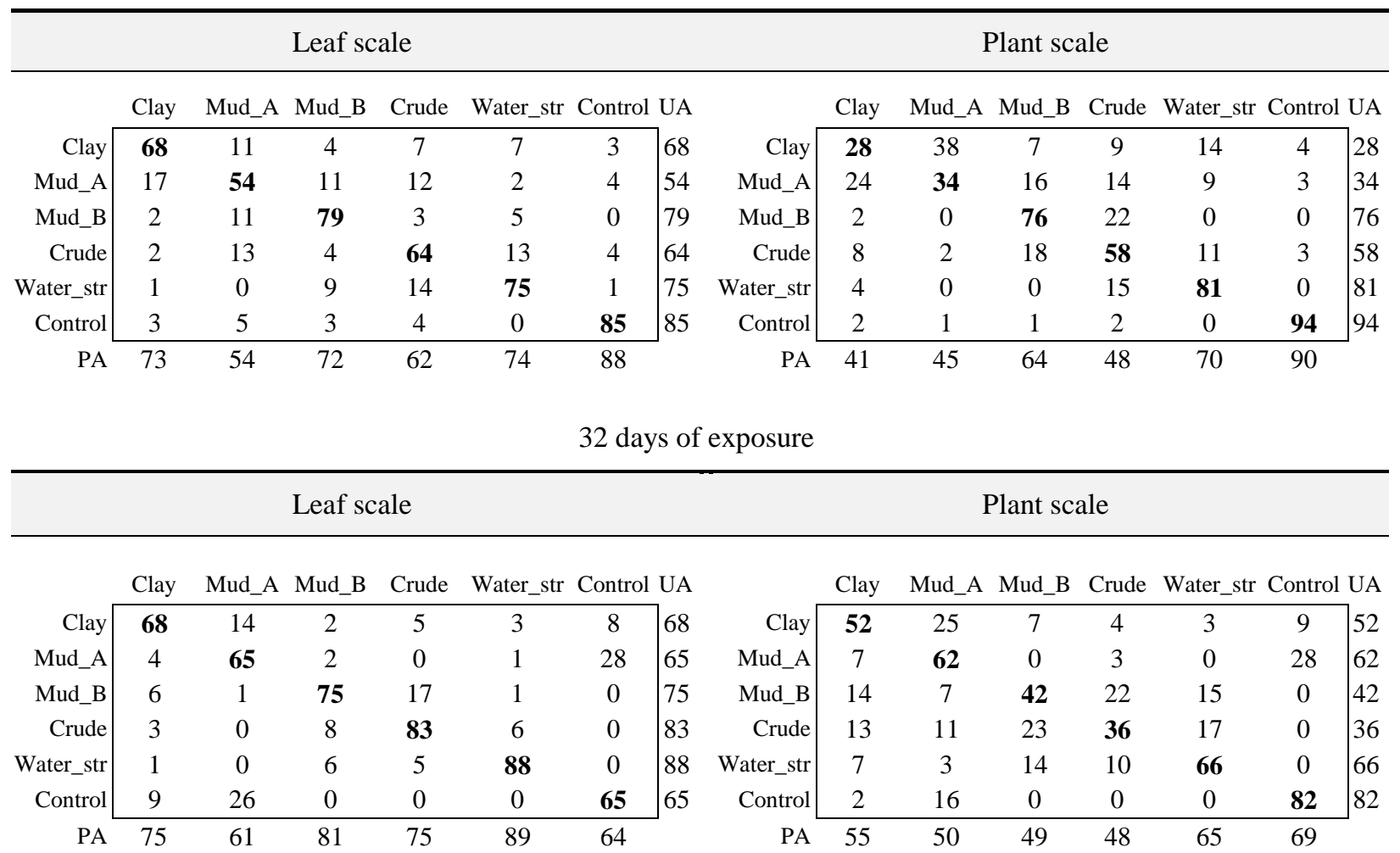




\subsection{Field validation}

Following training on leaf dataset from the greenhouse experiment, RLR classifications performed on brownfield canopy measurements allowed identifying 27 out of the 30 bramble patches (90\%) as Clay-exposed vegetation. The remaining ones were confused with Mud_A (7 $\%)$ and Control (3\%) treatments. These results were better than those obtained on the same treatment at leaf and plant scales at the end of the experiment (Tab. 5) and suggest involvement of additional factors in vegetation long-term response to TPH and HM under natural conditions. For example, Emengini et al. (2013a) showed that a combination of oil and water-deficit stress lead to stronger modifications of vegetation reflectance than oil stress alone. This might facilitate the discrimination with healthy vegetation. Of the 30 patches measured on uncontaminated sites, 25 were correctly labeled as Control (83\%). Confusions with Clay (3\%) and Mud_A (13\%) treatments were consistent with those observed for the Control after 32 days of experiment. These results thus demonstrated the potential of the approach developed under controlled conditions for discriminating among contaminated and uncontaminated soils under natural conditions.

\section{Conclusion and Perspectives}

This study aimed to demonstrate the potential of bramble reflectance for detecting and discriminating among various oil contaminations under controlled and natural conditions. Modifications of reflectance occurred from leaf to multi-plant scales under exposure to TPH and HM mixtures. This study revealed that the composition of mixtures is largely responsible for these modifications and determines their temporal evolution. A clear link was established 
between modifications of reflectance and the biochemical response of brambles using VI. This confirmed that chlorophylls are not the only pigments involved in the spectral response of vegetation to TPH and HM. Following a leaf-scale training approach, VI enabled discriminating among mixtures and with uncontaminated control and water-deficient soils, from leaf to multiplant scales. This highlighted the consequences of leaf biochemical alterations on the reflectance observed at higher scales. The results emphasized the importance of multitemporal acquisitions to ensure detection of various oil-contaminated soils at appropriate time. The soils contaminated by high levels of oil production residues or crude oil were particularly well detected after a prolonged time (32 days). Conversely, the best detection of low levels of production residues was obtained after a moderate time (18 days). VI showed great potential when applied under natural conditions.

The proposed method thus proved to be efficient for monitoring oil contamination at field scale. The diversity of soils being detected emphasizes the potential of this method for various operational applications, such as the detection of chronic pipeline leakages or soil contaminations resulting from past production activities. To expand its scope, the method needs to be assessed in other contexts, involving different plant species and oil contaminations. In that sense, upcoming study will focus on the tropical context, where the remote detection of oil remains a major challenge for environmental risk assessment. The method could be adapted to be applied to hyperspectral images with high spectral and spatial resolutions acquired from airborne or future satellite sensors. This represents a major challenge for a monitoring over large areas that will be addressed in future work. 
Acknowledgements

This collaborative work is part of the NAOMI R\&D project between TOTAL and the ONERA, with the support of Ecolab and Dynafor research units of Toulouse. The authors gratefully acknowledge Didier Lambrigot and Olivier Berseille for their assistance in pigment analysis.

Declarations of interest: None.

Funding: Financial support of this work was provided by TOTAL.

References

Adeniyi, A.A., Afolabi, J.A., 2002. Determination of total petroleum hydrocarbons and heavy metals in soils within the vicinity of facilities handling refined petroleum products in Lagos metropolis. Environ. Int. 28 (1-2), 79-82. https://doi.org/10.1016/S0160-4120(02)00007-7

Alonso, R., Elvira, S., Castillo, F.J., Gimeno, B.S. 2001. Interactive effects of ozone and drought stress on pigments and activities of antioxidative enzymes. Plant, Cell, Environ. 24 (9), 905-916. https://doi.org/10.1046/j.0016-8025.2001.00738.x

Angelliaume, S., Ceamanos, X., Viallefont-Robinet, F., Baqué, R., Déliot, P., Miegebielle, V., 2017. Hyperspectral and radar airborne imagery over controlled release of oil at sea. Sensors 17 (8). https://doi.org/10.3390/s17081772

Apan, A., Held, A., Phinn, S., Markley, J., 2004. Detecting sugarcane "orange rust" disease using EO-1 Hyperion hyperspectral imagery. Int. J. Remote Sens. 25 (2), 489-498. https://doi.org/10.1080/01431160310001618031

Arellano, P., Tansey, K., Balzter, H., Boyd, D.S., 2015. Detecting the effects of hydrocarbon pollution in the Amazon forest using hyperspectral satellite images. Environ. Pollut. 205, 225-239. https://doi.org/10.1016/j.envpol.2015.05.041

Arellano, P., Tansey, K., Balzter, H., Tellkamp, M., 2017. Plant family-specific impacts of petroleum pollution on biodiversity and leaf chlorophyll content in the Amazon rainforest of Ecuador. PLoS One 12 (1), 1-18. https://doi.org/10.1371/journal.pone.0169867

Asadzadeh, S., de Souza Filho, C.R., 2016. A review on spectral processing methods for geological remote sensing. Int. J. Appl. Earth Obs. Geoinf. 47, 69-90.

https://doi.org/10.1016/j.jag.2015.12.004 
Asner, G.P., 1998 Biophysical and biochemical sources of variability in canopy reflectance. Remote Sens. Environ. 253, 234-253.

Asner, G.P., Martin, R.E., 2008. Spectral and chemical analysis of tropical forests: Scaling from leaf to canopy levels. Remote Sens. Environ. 112, 3958-3970. https://doi.org/10.1016/j.rse.2008.07.003

Athar, H.-R., Ambreen, S., Javed, M., Hina, M., Rasul, S., Zafar, Z.U., Manzoor, H., Ogbaga, C.C., Afzal, M., Al-Qurainy, F., Ashraf, M., 2016. Influence of sub-lethal crude oil concentration on growth, water relations and photosynthetic capacity of maize (Zea mays L.) plants. Environ. Sci. Pollut. Res. 23 (18), 18320-18331. https://doi.org/10.1007/s11356016-6976-7

Balasubramaniyam, A., Harvey, P.J., 2014. Scanning electron microscopic investigations of root structural modifications arising from growth in crude oil-contaminated sand. Environ. Sci. Pollut. Res. 21 (22), 12651-12661. https://doi.org/10.1007/s11356-014-3138-7

Balliana, A.G., Moura, B.B., Inckot, R.C., Bona, C., 2017. Development of Canavalia ensiformis in soil contaminated with diesel oil. Environ. Sci. Pollut. Res. 24 (1), 979-986. https://doi.org/10.1007/s11356-016-7674-1

Barceló, J., Poschenrieder, C., 1990. Plant water relations as affected by heavy metal stress: A review. J. Plant Nutr. 13 (1), 1-37. https://doi.org/10.1080/01904169009364057

Barlow, R.G., Cummings, D.G., Gibb, S.W., 1997. Improved resolution of mono- and divinyl chlorophylls $\mathrm{a}$ and $\mathrm{b}$ and zeaxanthin and lutein in phytoplankton extracts using reverse phase C-8 HPLC. Mar. Ecol. Prog. Ser. 161, 303-307. https://doi.org/10.3354/meps161303

Baruah, P., Saikia, R.R., Baruah, P.P., Deka, S., 2014. Effect of crude oil contamination on the chlorophyll content and morpho-anatomy of Cyperus brevifolius (Rottb.) Hassk. Environ. Sci. Pollut. Res. 21, 12530-12538. https://doi.org/10.1007/s11356-014-3195-y

Belsley, D., Kuh, E., Welsch, R., 1980. Detecting and assessing collinearity. In: Belsley, D., Kuh, E., Welsch, R. Regression diagnostics: identifying influential data and sources of collinearity. John Wiley \& Sons. https://doi.org/10.1002/0471725153.ch3

Blackburn, G.A., 1998a. Quantifying chlorophylls and carotenoids at leaf and canopy scales. Remote Sens. Environ. 66, 273-285. https://doi.org/10.1016/S0034-4257(98)00059-5

Blackburn, G.A., 1998b. Spectral indices for estimating photosynthetic pigment concentrations: A test using senescent tree leaves. Int. J. Remote Sens. 19 (4), 657-675. https://doi.org/10.1080/014311698215919

Boelman, N.T., Magney, T.S., Logan, B.A., Griffin, K.L., Eitel, J.U.H., Greaves, H., Prager, C.M., Vierling, L.A., 2016. Spectral determination of concentrations of functionally diverse 
pigments in increasingly complex arctic tundra canopies. Oecologia 182, 85-97. https://doi.org/10.1007/s00442-016-3646-x

Carter, G.A., 1994. Ratios of leaf reflectances in narrow wavebands as indicators of plant stress. Int. J. Remote Sens. 15 (3), 517-520. https://doi.org/10.1080/01431169408954109

Ceccato, P., Flasse, S., Tarantola, S., Jacquemoud, S., Grégoire, J.M., 2001. Detecting vegetation leaf water content using reflectance in the optical domain. Remote Sens. Environ. 77, 2233. https://doi.org/10.1016/S0034-4257(01)00191-2

Chakraborty, S., Weindorf, D.C., Deb, S., Li, B., Paul, S., Choudhury, A., Ray, D.P., 2017. Rapid assessment of regional soil arsenic pollution risk via diffuse reflectance spectroscopy. Geoderma 289, 72-81. https://doi.org/10.1016/j.geoderma.2016.11.024

Credoz, A., Hédacq, R., Barreau, C., Dubucq, D., 2016. Experimental study of hyperspectral responses of plants grown on mud pit soil. Proc. SPIE 100051, Earth Resources and Environmental Remote Sensing/GIS Applications VII. https://doi.org/10.1117/12.2239606

Dash, J., Curran, P.J., 2007. Evaluation of the MERIS terrestrial chlorophyll index (MTCI). Adv. Sp. Res. 39, 100-104. https://doi.org/10.1016/j.asr.2006.02.034

Daughtry, C.S.T., Walthall, C.L., Kim, M.S., Brown de Colstoun, E., McMurtrey III, J.E., 2000. Estimating corn leaf chlorophyll concentration from leaf and canopy reflectance. Remote Sens. Environ. 74, 229-239. https://doi.org/10.1016/S0034-4257(00)00113-9

De Jong, S.M., Addink, E.A., Hoogenboom, P., Nijland, W., 2012. The spectral response of Buxus sempervirens to different types of environmental stress - A laboratory experiment. ISPRS J. Photogramm. Remote Sens. 74, 56-65. https://doi.org/10.1016/j.isprsjprs.2012.08.005

Diepens, N.J., Buffan-Dubau, E., Budzinski, H., Kallerhoff, J., Merlina, G., Silvestre, J., Auby, I., Nathalie Tapie, Elger, A., 2017. Toxicity effects of an environmental realistic herbicide mixture on the seagrass Zostera noltei. Environ. Pollut. 222, 393-403. https://doi.org/10.1016/j.envpol.2016.12.021

Dindar, E., Topaç Şağban, F.O., Başkaya, H.S., 2015. Variations of soil enzyme activities in petroleum-hydrocarbon contaminated soil. Int. Biodeterior. Biodegrad. 105, 268-275. https://doi.org/10.1016/j.ibiod.2015.09.011

Dormann, C.F., Elith, J., Bacher, S., Buchmann, C., Carl, G., Carré, G., Marquéz, J.R.G., Gruber, B., Lafourcade, B., Leitão, P.J., Münkemüller, T., Mcclean, C., Osborne, P.E., Reineking, B., Schröder, B., Skidmore, A.K., Zurell, D., Lautenbach, S., 2013. Collinearity: A review of methods to deal with it and a simulation study evaluating their performance. Ecography (Cop.). 36, 027-046. https://doi.org/10.1111/j.1600-0587.2012.07348.x 
Dorrington, V.H., Pyatt, F.B., 1983. Some aspects of tissue accumulation and tolerance to available heavy metal ions by Rubus fruticosus L., a colonizer of spoil tips in S.W. England. Int. J. Environ. Stud. 20, 229-237. https://doi.org/10.1080/00207238308710039

Elger, A., Barrat-Segretain, M.H., 2004. Plant palatability can be inferred from a single-date feeding trial. Funct. Ecol. 18, 483-488. https://doi.org/10.1111/j.0269-8463.2004.00846.x

Emengini, E.J., Blackburn, G.A., Theobald, J.C., 2013a. Detection and discrimination of oil and water deficit-induced stress in maize (Zea mays L.) using spectral and thermal responses. IOSR J. Environ. Sci. Toxicol. Food Technol. 3 (3), 2319 - 2402. 10.9790/2402-0335357

Emengini, E.J., Blackburn, G.A., Theobald, J.C., 2013b. Early detection of oil-induced stress in crops using spectral and thermal responses. J. Appl. Remote Sens. 7. https://doi.org/10.1117/1.JRS.7.073596

Emengini, E.J., Ezeh, F.C., Chigbu, N., 2013c. Comparative analysis of spectral responses of varied plant species to oil stress. Int. J. Sci. Eng. Res. 4 (6), 1421-1427.

Erudel, T., Fabre, S., Houet, T., Mazier, F., Briottet, X., 2017. Criteria comparison for classifying peatland vegetation types using in situ hyperspectral measurements. Remote Sens. 9, 748. https://doi.org/10.3390/rs9070748

Friedman, J.H., Popescu, B.E. 2004. Gradient directed regularization for linear regression and classification. Technical report, Dep. Statist. Dept. Statistics, Stanford Univ.

Galmés, J., Abadía, A., Cifre, J., Medrano, H., Flexas, J., 2007. Photoprotection processes under water stress and recovery in Mediterranean plants with different growth forms and leaf habits. Physiol. Plant. 130, 495-510. https://doi.org/10.1111/j.1399-3054.2007.00919.x

Gamon, J.A., Peñuelas, J., Field, C.B., 1992. A narrow-waveband spectral index that tracks diurnal changes in photosynthetic efficiency. Remote Sens. Environ. 41, 35-44. https://doi.org/10.1016/0034-4257(92)90059-S

Garbulsky, M.F., Peñuelas, J., Gamon, J., Inoue, Y., Filella, I., 2011. The photochemical reflectance index (PRI) and the remote sensing of leaf, canopy and ecosystem radiation use efficiencies. A review and meta-analysis. Remote Sens. Environ. 115, 281-297. https://doi.org/10.1016/j.rse.2010.08.023

Garg, N., Singla, P., 2011. Arsenic toxicity in crop plants: Physiological effects and tolerance mechanisms. Environ. Chem. Lett. 9, 303-321. https://doi.org/10.1007/s10311-011-0313-7

Gitelson, A.A., Merzlyak, M.N., 1997. Remote estimation of chlorophyll content in higher plant leaves. Int. J. Remote Sens. 18 (12), 37-41 https://doi.org/10.1080/014311697217558 
Gomez, C., Lagacherie, P., Coulouma, G., 2008. Continuum removal versus PLSR method for clay and calcium carbonate content estimation from laboratory and airborne hyperspectral measurements. Geoderma 148, 141-148. https://doi.org/10.1016/j.geoderma.2008.09.016

Haboudane, D., Miller, J.R., Pattey, E., Zarco-Tejada, P.J., Strachan, I.B., 2004. Hyperspectral vegetation indices and novel algorithms for predicting green LAI of crop canopies: Modeling and validation in the context of precision agriculture. Remote Sens. Environ. 90, 337-352. https://doi.org/10.1016/j.rse.2003.12.013

Haboudane, D., Miller, J.R., Tremblay, N., Zarco-Tejada, P.J., Dextraze, L., 2002. Integrated narrow-band vegetation indices for prediction of crop chlorophyll content for application to precision agriculture. Remote Sens. Environ. 81, 416-426. https://doi.org/10.1016/S00344257(02)00018-4

Hagemeyer, J., 1999. Ecophysiology of plant growth under heavy metal stress. In: Prasad, M.N.V., Hagemeyer, J. Heavy metal stress in plants. Springer Berlin Heidelberg. https://doi.org/10.1007/978-3-662-07745-0_8

Hoerl, A.E., Kennard, R.W., 1970. Ridge Regression: Biased Estimation for Problems Nonorthogonal. Technometrics 12 (1), 80-86. https://doi.org/10.1080 / 00401706.2000 .10485983

Hotelling, H., 1933. Analysis of a complex of statistical variables into principal components. Journal of Educational Psychology, 24 (6), 417-441. http://dx.doi.org/10.1037/h0071325

Jolliffe, I.T., 2002. Principal Component Analysis. Second Edition. Springer-Verlag New York. https://doi.org/10.2307/1270093

Kendall, M.G., Smith, B.B., 1939. The Problem of $m$ Rankings. Ann. Math. Stat. 10 (3), 275287. https://doi.org/10.1214/aoms/1177732186

Khamehchiyan, M., Hossein Charkhabi, A., Tajik, M., 2007. Effects of crude oil contamination on geotechnical properties of clayey and sandy soils. Eng. Geol. 89, 220-229. https://doi.org/10.1016/j.enggeo.2006.10.009

Kim, M.S., Daughtry, C.S.T., Chappelle, E.W., McMurtrey, J.E., Walthall, C.L., 1994, The use of high spatial resolution bands for estimating absorbed photosynthetically active radiation $\left(\mathrm{A}_{\mathrm{par}}\right)$. Proceedings of the 6th Symposium on Physical Measurements and Signatures in Remote Sensing, January 17 - 21, 1994, Val D'Isère, France, 299 - 306.

Kisic, I., Mesic, S., Basic, F., Brkic, V., Mesic, M., Durn, G., Zgorelec, Z., Bertovic, L., 2009. The effect of drilling fluids and crude oil on some chemical characteristics of soil and crops. Geoderma 149, 209-216. https://doi.org/10.1016/j.geoderma.2008.11.041 
Konik, M., Bradtke, K., 2016. Object-oriented approach to oil spill detection using ENVISAT ASAR images. ISPRS J. Photogramm. Remote Sens. 118, 37-52. https://doi.org/10.1016/j.isprsjprs.2016.04.006

Kvesitadze, G., Khatisashvili, G., Sadunishvili, T., Ramsden, J.J., 2006. Biochemical mechanisms of detoxification in higher plants. Springer-Verlag Berlin Heidelberg. https://doi.org/10.1017/CBO9781107415324.004

Lassalle, G., Credoz, A., Fabre, S., Hédacq, R., Dubucq, D., Elger, A., 2017. Hyperspectral signature analysis of three plant species to long-term hydrocarbon and heavy metal exposure. Proc. SPIE 10428, Earth Resources and Environmental Remote Sensing/GIS Applications VIII. https://doi.org/10.1117/12.2277709

Lassalle, G., Credoz, A., Hédacq, R., Fabre, S., Dubucq, D., Elger, A., 2018. Assessing soil contamination due to oil and gas production using vegetation hyperspectral reflectance. Environ. Sci. Technol. 52 (4), 1756-1764. https://doi.org/10.1021/acs.est.7b04618

Legendre, P., 2005. Species associations: The Kendall coefficient of concordance revisited. J. Agric. Biol. Environ. Stat. 10 (2), 226-245. https://doi.org/10.1198/108571105X46642

Leifer, I., Lehr, W.J., Simecek-Beatty, D., Bradley, E., Clark, R., Dennison, P., Hu, Y., Matheson, S., Jones, C.E., Holt, B., Reif, M., Roberts, D.A., Svejkovsky, J., Swayze, G., Wozencraft, J., 2012. State of the art satellite and airborne marine oil spill remote sensing: Application to the BP Deepwater Horizon oil spill. Remote Sens. Environ. 124, 185-209. https://doi.org/10.1016/j.rse.2012.03.024

Lichtenthaler, H.K., Lang, M., Sowinska, M., Heisel, F., Miehé, J.A., 1996. Detection of vegetation stress via a new high resolution fluorescence imaging system. J. Plant Physiol. 148, 599-612. https://doi.org/10.1016/S0176-1617(96)80081-2

Logan, G.A., Jones, A.T., Kennard, J.M., Ryan, G.J., Rollet, N., 2010. Australian offshore natural hydrocarbon seepage studies, a review and re-evaluation. Mar. Pet. Geol. 27, 26-45. https://doi.org/10.1016/j.marpetgeo.2009.07.002

Merkl, N., Schultze-Kraft, R., Infante, C., 2005. Phytoremediation in the tropics - Influence of heavy crude oil on root morphological characteristics of graminoids. Environ. Pollut. 138, 86-91. https://doi.org/10.1016/j.envpol.2005.02.023

Merzlyak, M.N., Gitelson, A.A., Chivkunova, O.B., Rakitin, V.Y., 1999. Non-destructive optical detection of leaf senescence and fruit ripening. Physiol. Plant 106, 135.

Metwally, M.E.S., Al-Muzaini, S., Jacob, P.G., Bahloul, M., Urushigawa, Y., Sato, S., Matsmura, A., 1997. Petroleum hydrocarbons and related heavy metals in the near-shore marine sediments of Kuwait. Environ. Int. 23 (1), 115-121. https://doi.org/10.1016/S01604120(96)00082-7 
Milton, E.J., 1987. Principles of field spectroscopy - Review Article. Int. J. Remote Sens. 8 (12), 1807-1827. https://doi.org/10.1080/01431168708954818

Nagajyoti, P.C., Lee, K.D., Sreekanth, T.V.M., 2010. Heavy metals, occurrence and toxicity for plants: A review. Environ. Chem. Lett. 8, 199-216. https://doi.org/10.1007/s10311-0100297-8

Nie, M., Lu, M., Yang, Q., Zhang, X.D., Xiao, M., Jiang, L.F., Yang, J., Fang, C.M., Chen, J.K., Li, B., 2011. Plants' use of different nitrogen forms in response to crude oil contamination. Environ. Pollut. 159, 157-163. https://doi.org/10.1016/j.envpol.2010.09.013

Nie, M., Xian, N., Fu, X., Chen, X., Li, B., 2010. The interactive effects of petroleumhydrocarbon spillage and plant rhizosphere on concentrations and distribution of heavy metals in sediments in the Yellow River Delta, China. J. Hazard. Mater. 174, 156-161. https://doi.org/10.1016/j.jhazmat.2009.09.030

Noomen, M.F., van der Werff, H.M.A., van der Meer, F.D., 2012. Spectral and spatial indicators of botanical changes caused by long-term hydrocarbon seepage. Ecol. Inform. 8, 55-64. https://doi.org/10.1016/j.ecoinf.2012.01.001

Nujkić, M.M., Dimitrijević, M.M., Alagić, S., Tošić, S.B., Petrović, J. V., 2016. Impact of metallurgical activities on the content of trace elements in the spatial soil and plant parts of Rubus fruticosus L. Environ. Sci. Process. Impacts 18, 350-360. https://doi.org/10.1039/c5em00646e

Parrish, Z.D., White, J.C., Isleyen, M., Gent, M.P.N., Iannucci-Berger, W., Eitzer, B.D., Kelsey, J.W., Mattina, M.I., 2006. Accumulation of weathered polycyclic aromatic hydrocarbons (PAHs) by plant and earthworm species. Chemosphere 64, 609-618. https://doi.org/10.1016/j.chemosphere.2005.11.003

Pearson, K., 1901. LIII. On lines and planes of closest fit to systems of points in space. The London, Edinburgh, and Dublin Philosophical Magazine and Journal of Science 2, 559572. https://doi.org/10.1080/14786440109462720

Pedregosa, F., Varoquaux, G., Gramfort, A., Michel, V., Thirion, B., Grisel, O., Blondel, M., Prettenhofer, P., Weiss, R., Dubourg, V., Vanderplas, J., Passos, A., Cournapeau, D., Brucher, M., Perrot, M., Duchesnay, É., 2011. Scikit-learn: Machine Learning in Python. J. Mach. Learn. Res. 12, 2825-2830

Peñuelas, J., Gamon, J. A., Fredeen, A.L., Merino, J., Field, C.B., 1994. Reflectance indices associated with physiological changes in Nitrogen - and water - limited sunflower leaves. Remote Sens. Environ. 48, 135-146.

Percival, D.C., Proctor, J.T.A., Privé, J.P., 1998. Gas exchange, stem water potential and leaf orientation of Rubus idaeus L. are influenced by drought stress. J. Hortic. Sci. Biotechnol. 73 (6), 831-840. https://doi.org/10.1080/14620316.1998.11511056 
Pérez-Hernández, I., Ochoa-Gaona, S., Adams, R.H., Rivera-Cruz, M.C., Pérez-Hernández, V., Jarquín-Sánchez, A., Geissen, V., Martínez-Zurimendi, P., 2017. Growth of four tropical tree species in petroleum-contaminated soil and effects of crude oil contamination. Environ. Sci. Pollut. Res. 24 (2), 1769-1783. https://doi.org/10.1007/s11356-016-7877-5

Pini, R., Pedron, F., Petruzzelli, G., Scatena, M., Guidi, G.V., 2009. Modifications of the structural characteristics of new soil forming on industrial waste colonized by woody plants. Geoderma 149, 373-378. https://doi.org/10.1016/j.geoderma.2008.12.017

Oliphant, T.E., 2007. Python for scientific computing. Computing Sci. Eng. 9, 10-20.

Rondeaux, G., Steven, M., Baret, F., 1996. Optimization of soil-adjusted vegetation indices. Remote Sens. Environ. 55, 95-107. https://doi.org/10.1016/0034-4257(95)00186-7

Rosso, P.H., Pushnik, J.C., Lay, M., Ustin, S.L., 2005. Reflectance properties and physiological responses of Salicornia virginica to heavy metal and petroleum contamination. Environ. Pollut. 137, 241-252. https://doi.org/10.1016/j.envpol.2005.02.025

Sanches, I.D., Souza Filho, C.R., Magalhães, L.A., Quitério, G.C.M., Alves, M.N., Oliveira, W.J., 2013a. Assessing the impact of hydrocarbon leakages on vegetation using reflectance spectroscopy. ISPRS J. Photogramm. Remote Sens. 78, 85-101. https://doi.org/10.1016/j.isprsjprs.2013.01.007

Sanches, I.D., Souza Filho, C.R., Magalhães, L.A., Quitério, G.C.M., Alves, M.N., Oliveira, W.J., 2013b. Unravelling remote sensing signatures of plants contaminated with gasoline and diesel: An approach using the red edge spectral feature. Environ. Pollut. 174, 16-27. https://doi.org/10.1016/j.envpol.2012.10.029

Savitzky, A., Golay, M.J.E., 1964. Smoothing and Differentiation of Data by Simplified Least Squares Procedures. Anal. Chem. 36 (8), 1627-1639. https://doi.org/10.1021/ac60214a047

Scafutto, R.D.P.M., de Souza Filho, C.R., Rivard, B., 2016. Characterization of mineral substrates impregnated with crude oils using proximal infrared hyperspectral imaging. Remote Sens. Environ. 179, 116-130. https://doi.org/10.1016/j.rse.2016.03.033

Scafutto, R.D.P.M., de Souza Filho, C.R., de Oliveira, W.J., 2017. Hyperspectral remote sensing detection of petroleum hydrocarbons in mixtures with mineral substrates: Implications for onshore exploration and monitoring. ISPRS J. Photogramm. Remote Sens. 128, 146-157. https://doi.org/10.1016/j.isprsjprs.2017.03.009

Seabold, S., Perktold, J., 2010. Statsmodels: Econometric and statistical modeling with python. Proc 9th Python Sci. Conf. 57-61.

Semple, K.T., Morriss, A.W.J., Paton, G.I., 2003. Bioavailability of hydrophobic organic contaminants in soils: fundamental concepts and techniques for analysis. Eur. J. Soil Sci. 54, 809-818. https://doi.org/10.1046/j.1365-2389.2003.00564.x 
Shanker, A.K., Cervantes, C., Loza-Tavera, H., Avudainayagam, S., 2005. Chromium toxicity in plants. Environ. Int. 31, 739-753. https://doi.org/10.1016/j.envint.2005.02.003

Shvaleva, A.L., Silva, F.C.E., Breia, E., Jouve, L., Hausman, J.F., Almeida, M.H., Maroco, J.P., Rodrigues, M.L., Pereira, J.S., Chaves, M.M., 2006. Metabolic responses to water deficit in two Eucalyptus globulus clones with contrasting drought sensitivity. Tree Physiol. 26, 239248. https://doi.org/10.1093/treephys/26.2.239

Sims, D.A., Gamon, J.A., 2002. Relationships between leaf pigment content and spectral reflectance across a wide range of species, leaf structures and developmental stages. Remote Sens. Environ. 81, 337-354. https://doi.org/10.1016/S0034-4257(02)00010-X

Sims, D.A., Luo, H., Hastings, S., Oechel, W.C., Rahman, A.F., Gamon, J.A., 2006. Parallel adjustments in vegetation greenness and ecosystem $\mathrm{CO}_{2}$ exchange in response to drought in a Southern California chaparral ecosystem. Remote Sens. Environ. 103, 289-303. https://doi.org/10.1016/j.rse.2005.01.020

Slaton, M.R., Hunt, E.R., Smith, W.K., 2001. Estimating near-infrared leaf reflectance from leaf structural characteristics. Am. J. Bot. 88 (2), 278-284. https://doi.org/10.2307/2657019

Smith, K.L., Steven, M.D., Colls, J.J., 2005. Plant spectral responses to gas leaks and other stresses. Int. J. Remote Sens. 26 (18), 4067-4081. https://doi.org/10.1080/01431160500165625

Stimson, H.C., Breshears, D.D., Ustin, S.L., Kefauver, S.C., 2005. Spectral sensing of foliar water conditions in two co-occurring conifer species: Pinus edulis and Juniperus monosperma. Remote Sens. Environ. 96, 108-118.

https://doi.org/10.1016/j.rse.2004.12.007

Story, M., Congalton, R.G., 1986. Accuracy assessment: A user's perspective. Photogramm. Eng. Remote Sensing 52(3), 397-399.

Stylinski, C.D., Gamon, J.A., Oechel, W.C., 2002. Seasonal patterns of reflectance indices, carotenoid pigments and photosynthesis of evergreen chaparral species. Oecologia 131, 366-374. https://doi.org/10.1007/s00442-002-0905-9

Su, Y.H., Zhu, Y.G., 2008. Uptake of selected PAHs from contaminated soils by rice seedlings (Oryza sativa) and influence of rhizosphere on PAH distribution. Environ. Pollut. 155, 359365. https://doi.org/10.1016/j.envpol.2007.11.008

Tao, S., Cui, Y.H., Xu, F.L., Li, B.G., Cao, J., Liu, W.X., Schmitt, G., Wang, X.J., Shen, W.R., Qing, B.P., Sun, R., 2004. Polycyclic aromatic hydrocarbons (PAHs) in agricultural soil and vegetables from Tianjin. Sci. Total Environ. 320, 11-24. https://doi.org/10.1016/S00489697(03)00453-4 
Tuia, D., Flamary, R., Barlaud, M., 2016. Nonconvex regularization in remote sensing. IEEE Trans. Geosci. Remote Sens. 54 (11), 6470-6480.

https://doi.org/10.1109/TGRS.2016.2585201

United States Environmental Protection Agency (EPA), 2014. Priority pollutant list. https://www.gpo.gov.

van der Werff, H., Van Der Meijde, M., Jansma, F., Van Der Meer, F., Groothuis, G.J., 2008. A spatial-spectral approach for visualization of vegetation stress resulting from pipeline leakage. Sensors 8, 3733-3743. https://doi.org/10.3390/s8063733

Vogelmann, J.E., Rock, B.N., Moss, D.M., 1993. Red edge spectral measurements from sugar maple leaves. Int. J. Remote Sens. 14 (8), 1563-1575.

https://doi.org/10.1080/01431169308953986

Wang, Z., Fingas, M., Page, D.S., 1999. Oil spill identification. J. Chromatrogr. A. 843, 369-411.

Wang, F., Gao, J., Zha, Y., 2018. Hyperspectral sensing of heavy metals in soil and vegetation: Feasibility and challenges. ISPRS J. Photogramm. Remote Sens. 136, 73-84. https://doi.org/10.1016/j.isprsjprs.2017.12.003

Wei, C., Huang, J., Wang, X., Blackburn, G.A., Zhang, Y., Wang, S., Mansaray, L.R., 2017. Hyperspectral characterization of freezing injury and its biochemical impacts in oilseed rape leaves. Remote Sens. Environ. 195, 56-66. https://doi.org/10.1016/j.rse.2017.03.042

Xiao, Y., Zhao, W., Zhou, D., Gong, H., 2014. Sensitivity analysis of vegetation reflectance to biochemical and biophysical variables at leaf, canopy, and regional scales. IEEE Trans. Geosci. Remote Sens. 52 (7), 4014-4024. https://doi.org/10.1109/TGRS.2013.2278838

Yilmaz, M.T., Hunt, E.R., Jackson, T.J., 2008. Remote sensing of vegetation water content from equivalent water thickness using satellite imagery. Remote Sens. Environ. 112, 2514-2522. https://doi.org/10.1016/j.rse.2007.11.014

Yoon, J., Cao, X., Zhou, Q., Ma, L.Q., 2006. Accumulation of $\mathrm{Pb}, \mathrm{Cu}$, and $\mathrm{Zn}$ in native plants growing on a contaminated Florida site. Sci. Total Environ. 368, 456-464. https://doi.org/10.1016/j.scitotenv.2006.01.016

Zarco-Tejada, P.J., Miller, J.R., Noland, T.L., Mohammed, G.H., Sampson, P.H., 2001. Scalingup and model inversion methods with narrowband optical indices for chlorophyll content estimation in closed forest canopies with hyperspectral data. IEEE Trans. Geosci. Remote Sens. 39 (7), 1491-1507. https://doi.org/10.1109/36.934080

Zhang, X., Hu, B., Ma, X., Xu, L., 2015. Resting-state whole-brain functional connectivity networks for MCI classification using L2-regularized logistic regression. IEEE Trans. Nanobioscience 14 (2), 237-247. https://doi.org/10.1109/TNB.2015.2403274 
Zhang, Y., Huang, J., Wang, F., Blackburn, G.A., Zhang, H.K., Wang, X., Wei, C., Zhang, K., Wei, C., 2017. An extended PROSPECT: Advance in the leaf optical properties model separating total chlorophylls into chlorophyll a and b. Sci. Rep. 7, 1-10. https://doi.org/10.1038/s41598-017-06694-y

Zhu, L., Chen, Z., Wang, J., Ding, J., Yu, Y., Li, J., Xiao, N., Jiang, L., Zheng, Y., Rimmington, G.M., 2014. Monitoring plant response to phenanthrene using the red edge of canopy hyperspectral reflectance. Mar. Pollut. Bull. 86, 332-341. https://doi.org/10.1016/j.marpolbul.2014.06.046

Zinnert, J.C., Via, S.M., Young, D.R., 2013. Distinguishing natural from anthropogenic stress in plants: Physiology, fluorescence and hyperspectral reflectance. Plant Soil 366, 133-141. https://doi.org/10.1007/s11104-012-1414-1

Zou, H., Hastie, T., 2005. Regularization and variable selection via the elastic net. J. R. Stat. Soc. Ser. B 67 (2), 301 - 320. https://doi.org/10.1111/j.1467-9868.2005.00527.x 